\title{
WHO SHOULD OWN AND CONTROL URBAN WATER SYSTEMS? HISTORICAL EVIDENCE FROM ENGLAND AND WALES
}

\author{
Brian Beach \\ Werner Troesken \\ Nicola Tynan \\ Working Paper 22553 \\ http://www.nber.org/papers/w22553 \\ NATIONAL BUREAU OF ECONOMIC RESEARCH \\ 1050 Massachusetts Avenue \\ Cambridge, MA 02138 \\ August 2016
}

For helpful suggestions, we thank seminar participants at Northwestern University and UCLA, as well as the Economic History Society, Economic and Business History, and Southern Economic Association's annual meetings. Artemis Yang provided outstanding research assistance. The views expressed herein are those of the authors and do not necessarily reflect the views of the National Bureau of Economic Research.

NBER working papers are circulated for discussion and comment purposes. They have not been peer-reviewed or been subject to the review by the NBER Board of Directors that accompanies official NBER publications.

(C) 2016 by Brian Beach, Werner Troesken, and Nicola Tynan. All rights reserved. Short sections of text, not to exceed two paragraphs, may be quoted without explicit permission provided that full credit, including $\odot$ notice, is given to the source. 
Who Should Own and Control Urban Water Systems? Historical Evidence from England and

Wales

Brian Beach, Werner Troesken, and Nicola Tynan

NBER Working Paper No. 22553

August 2016

JEL No. H51,H54,I18,N13

\section{ABSTRACT}

Nearly $40 \%$ of England's privately built waterworks were municipalised in the late 19th century. We examine how this affected public health by pairing annual mortality data for over 600 registration districts, spanning 1869 to 1910, with detailed waterworks information. Identification is aided by both institutional hurdles and idiosyncratic delays in the municipalisation process. Municipalisation lowered deaths from typhoid fever, a waterborne disease, by nearly $20 \%$ but deaths from non-waterborne causes were unaffected. Results are also robust to the adoption of several strategies that control for the possibility of mean reversion and other potential confounds.

Brian Beach

Department of Economics College of William \& Mary

PO Box 8795

Williamsburg, VA 23187

bbbeach@wm.edu

Werner Troesken

Department of Economics

University of Pittsburgh

Pittsburgh, PA 15260

and NBER

troesken@pitt.edu
Nicola Tynan

Department of Economics

Dickinson College

tynann@ dickinson.edu 


\section{Introduction}

During the late nineteenth and early twentieth century, nearly 40 percent of Britain's more than 300 privately built waterworks became publicly owned. This transition also occurred in other parts of Western Europe and the United States such that by the mid twentieth century municipally-owned waterworks were the norm in much of the world (Thompson 1917; Grafton et al. 2015). While recent privatization movements have reversed some of this, municipal ownership remains a common form of organization in the water industry. Consequently, the origins and effects of the original municipalisation movement have been the object much study as they have clear implications for modern debates surrounding privatization. Although advocates of municipal ownership argued that the transition to public ownership was associated with sharp reductions in waterborne disease rates, particularly typhoid fever, thus far economic historians have been reluctant to attribute a causal relationship between disease and ownership regimes (Falkus 1977; Hassan 1985). In this paper, we revisit the argument that municipal ownership reduced waterborne disease rates using a standard difference-in-difference framework. We construct a panel spanning from 1869 to 1910 by collecting detailed waterworks information for over 500 waterworks, which are then paired with annual district-level mortality data for each of the nearly 650 districts that span England and Wales. We exploit the variation in the timing of public acquisition to study the origins and effects of the switch to municipal ownership, particularly in relation to typhoid fever (a waterborne disease).

In terms of the origins of municipalisation, results indicate that while contemporaneous typhoid rates do not explain municipalisation, lagged typhoid rates do: cities tended to municipalise in the wake of persistent and rising typhoid rates. We also find that the timing of municipalisation was heavily influenced by national laws and local political institutions, which made all switches to municipal ownership permanent and made it impossible for cities to respond instantaneously to high disease rates. Because typhoid rates were rising steadily in the years preceding municipalisation, mean reversion threatens any effort to identify the effects of municipalisation on disease rates using a difference-in-differences strategy. Hence we adopt multiple strategies to test, and control for, mean reversion. We also control for other potential confounders, such as the 
simultaneous expansion in local sewer systems. Results are robust to these various strategies and indicate that deaths from typhoid fever fell by 19 percent in the years following municipalisation.

Although prior research has explored how changes in ownership regimes affect waterborne disease rates, that research yields conflicting results and is limited to Argentina (Galiani et al. 2005) and the United States (Troesken 1999, 2001). The data and identification strategies we employ promise to help reconcile these conflicting results and allow us to better disentangle the effects of waterborne disease epidemics and changes in ownership regimes. In the process of identifying the effects of municipal ownership on waterborne disease rates, we not only contribute to an understanding of an economic and political process that has affected cities the world over but also address a fundamental question in public policy: who should own and control urban water systems? When placed in the context of the current literature, our results suggest there is probably not a general answer to this question. Instead, the efficacy of any ownership regime appears to depend on the broader economic and institutional setting.

Three observations motivate the broader significance of our inquiry. First, what happened in England during the nineteenth and early twentieth century was not unique. Cities throughout Europe and the Americas municipalised their water systems during this period, often acquiring private water companies through voluntary sales but also through seizures and forced sales (Thompson 1917). Today, public ownership for water is the rule in much of Europe and North America (Pérard, 2009; AquaFed, 2010), but it is not immediately obvious that such an ownership regime is optimal and many countries have a mix of public and private ownership. ${ }^{1}$ One way to assess the efficiency of today's prevailing ownership regime is to explore its historical origins and effects. Did municipal ownership emerge, for example, because alternative ownership regimes were failing to provide adequate service, and once municipal ownership emerged, did the provision of services improve? The results in this paper suggest that a subset of private water companies underinvested in disease prevention, possibly because they were credit constrained in the face of rapid population growth, and that local disease environments

\footnotetext{
${ }^{1}$ England and Wales saw a return to private provision in 1989, while, in 2010, Paris ended a long history of private participation in water management.
} 
improved sharply once those companies were municipalised. The available evidence suggests improvements to local water systems generally yielded high rates of social return (Beach et al. 2016, Cutler and Miller 2005, and Ferrie and Troesken 2008). Thus, given the magnitude of our findings, it is likely that municipalisation played an important role in shaping public health during this time period.

Second, in more recent years, advocates of liberalization in Latin America, Africa, and other lesser-developed regions have pointed to privatization as a key element of improving economic performance, and it would be desirable to have a better understanding of just how far the benefits of privatization might extend. Can one expect privatization, or its converse, municipalisation, to work similarly in all historical settings and national contexts? It is possible, for example, that private ownership might be better suited for places where corruption and political dysfunction are commonplace, while municipal ownership might work better in places with well-functioning political institutions. In this regard, a 1996 New York Times article described Argentina as a place where "payoffs, kickbacks, and government bribes are considered a part of everyday life..." To the extent that government corruption in Argentina is so pervasive, it helps to rationalize and explain the strong evidence in Galiani et al. (2005) that privatizing water systems in Argentina during the 1990s reduced infant mortality rates, especially among poor socioeconomic groups. On the other hand, Troesken (2001) presents evidence that municipalisation (the exact opposite process of privatization) reduced waterborne disease in the United States, and the benefits were concentrated largely among poor socioeconomic groups such as the foreign born and African Americans. Troesken and Geddes (2003) present evidence that the gains to municipal ownership stemmed from insecure property rights: some municipalities in the US could not credibly commit to not expropriating value from private companies, and so private companies rationally reduced their investments, which in turn provided the motivation for municipalisation. As we explain below, exploring the effects of municipalisation in Victorian Britain can help us better understand why private ownership works relatively well in some institutional contexts (e.g., Argentina) but not others (e.g., some American cities).

Third, in their recent paper, "Democracy Does Cause Growth," Acemoglu et al. (2014) emphasize the importance of controlling for the "rich dynamics" of economic 
change in countries that switch from autocracy to democracy. In particular, they show that democratization typically occurs in the wake of serious economic downturns and as a result, it is easy for researchers interested in identifying the effects of democratization on economic growth to conflate the natural mean-reverting process that follows a recession with the effects of democratization. A similar problem confronts researchers who want to identify the effects of municipalisation on waterborne disease rates. As our data show, municipalisation typically followed a period of rising typhoid fever rates. Failure to control for trends and cyclicality in typhoid over time could lead researchers to misestimate the effects of municipalisation on disease rates. We construct a panel that expands forty years, which allows us to fully control for the dynamics of typhoid fever. ${ }^{2}$

\section{Political economy of municipalisation}

Mortality in Britain declined by roughly 20 percent between 1850 and 1900 . Recent research emphasizes the role of public health initiatives as the cause of this decline. As Szreter (1992: 2) argues, "public health measures played the most decisive and quantitatively most important role in the early stages [1860-1900] of the mortality decline." Indeed, expansion of waterworks and increased municipal responsibility for water provision were key public health measures, as was improved sewerage and street cleaning. Chapman (2016) estimates that investment in local water supplies, sewers, and roads accounted for roughly one-fourth to one-half of the mortality decline. The United States experienced a similar mortality decline as well as a similar expansion in local water supplies. There, the empirical evidence suggests that 50 to 60 percent of the American mortality decline can be attributed to improvements in public water supplies alone (Cutler and Miller, 2005; Ferrie and Troesken, 2008).

Given this evidence, it is now generally accepted that the expansion of waterworks and investment in water purification technologies played an important role for public health. What is less clear is the extent to which public versus private ownership matters for public health. In addition, recent work by Alsan and Goldin (2015) and

\footnotetext{
2 Our results are also loosely related to recent work by Antman (2016), who explores how the rise of tea consumption during the $18^{\text {th }}$ century inadvertently reduced waterborne diseases because tea drinkers first had to boil their water. What is particularly interesting about Antman's findings is that during the $18^{\text {th }}$ century no one understood the link between impure water and disease.
} 
Ketzenbaum and Rosenthal (2014) shows that sewers can be an important confounding variable when scholars try to estimate the effects of improved water systems on health. An important and novel aspect of our paper is that we are able to control for the possibility that improvements in sewer systems happened concurrently with the public acquisition of private waterworks. By contrast, many recent studies looking at the effects of changes in ownership regimes on waterborne mortality have been unable to fully separate the effects of changes in ownership regimes and expansions in sewer systems (e.g., Troesken 2001).

In Britain, public ownership was never an explicit requirement. In fact, prior to 1860, nearly 70 percent of British waterworks were privately built, in part because public services such as waterworks were unlikely receive local political support before the Reform Acts of 1832 and $1867 .^{3}$ Most of these early waterworks were established by private companies under individual acts of Parliament. ${ }^{4}$ Consequently, this system produced substantial variation in the rights, obligations, and privileges of each company as well as the associated local government. Following the Joint-Stock Companies Act of 1856, however, small, provincial, waterworks could be established as limited liability companies without going through parliament. ${ }^{5}$

In many ways, the process for establishing a new waterworks was the same for private companies and local governments: most had to seek central government approval through a private bill in Parliament. After the creation of the Local Government Board in 1871, local governments could seek authority from the Board and avoid a costly act of Parliament but some continued to seek Parliamentary approval. Management of a municipal waterworks was similar to that of a private company and usually delegated to a committee of the town council operating as a board of directors (Knoop 1912: 107-8). A

\footnotetext{
${ }^{3}$ More precisely, Lizzeri and Persico (2004) argue that extension of the franchise to the middle and lower classes gave rise to Parliamentary reforms that allowed municipal corporations to invest in public goods and access the necessary financing.

${ }^{4}$ In addition to these statutory water companies, a few older waterworks were established by individual landowners or charitable organizations.

${ }^{5}$ Three acts were involved: the Joint-Stock Companies Act 1844 allowed non-mining companies to form through a registration process rather than individual act of Parliament; the 1855 Limited Liability Act gave shareholders limited liability for company debts, and the Joint-Stock Companies Act 1856 consolidated these two acts and created the modern register of companies. Until 1856, the cost of registration was sufficiently high to preclude all but the largest from achieving company status (Amsler et al. 1981: 778).
} 
key difference between municipal and private companies was who acted as the residual claimant. Under private provision, shareholders were the residual claimant, while under municipal ownership voters were, at least in theory, the residual claimant. This difference played a central role in debates about the desirability of public ownership. Critics of private provision argued that the quest for dividends and earnings for shareholders would always trump concerns over public health water quality. In practical terms, this view implied that private companies would defer important investments in disease prevention and charge exorbitant rates for water. Champions of private provision, however, countered that municipally owned firms were rife with patronage employees (suggesting, in effect, that the patronage employees, not voters, were the residual claimant) and that concerns over water quality could be adequately addressed through appropriate contracting and regulatory mechanisms. ${ }^{6}$

Over the course of the nineteenth century, many private water companies were taken over by municipal governments. Companies were usually municipalised at a rate of 1 to 4 companies per year, though the municipalisation rate could reach as a high as 9 or 10 companies per year (as it did 1878 and 1898). Capturing the effects of both municipalisation and the relative rate of construction of new public and private water works, Figure 1 shows how municipal ownership grew increasingly popular in England over the course of the nineteenth and early twentieth century. Just under 40 percent of England's waterworks were municipally owned in 1860 , but by 1910 the figure was closer to 62 percent. Notice that there are two sharp increases in the municipal ownership share. The first upward break in trend occurs during the late 1870s, and the second occurs during the late 1890s. In particular between 1877 and 1880, the proportion of waterworks that were municipally owned rose from about 42 to 52 percent, between 1895 and 1900 the proportion rose from 55 to 60 percent. As we explain below, these breaks are associated with passage of two national laws.

\footnotetext{
${ }^{6}$ See Troesken $(1999,2001)$ for reviews of these arguments in the American context. For a review of these arguments in the British setting, see the collection of articles from the London Times compiled in Municipal Socialism: A Series of Articles Reprinted from the Times (London: Printed and Published by George Edward Wright, 1902).
} 
Figure 1: Public ownership share over time

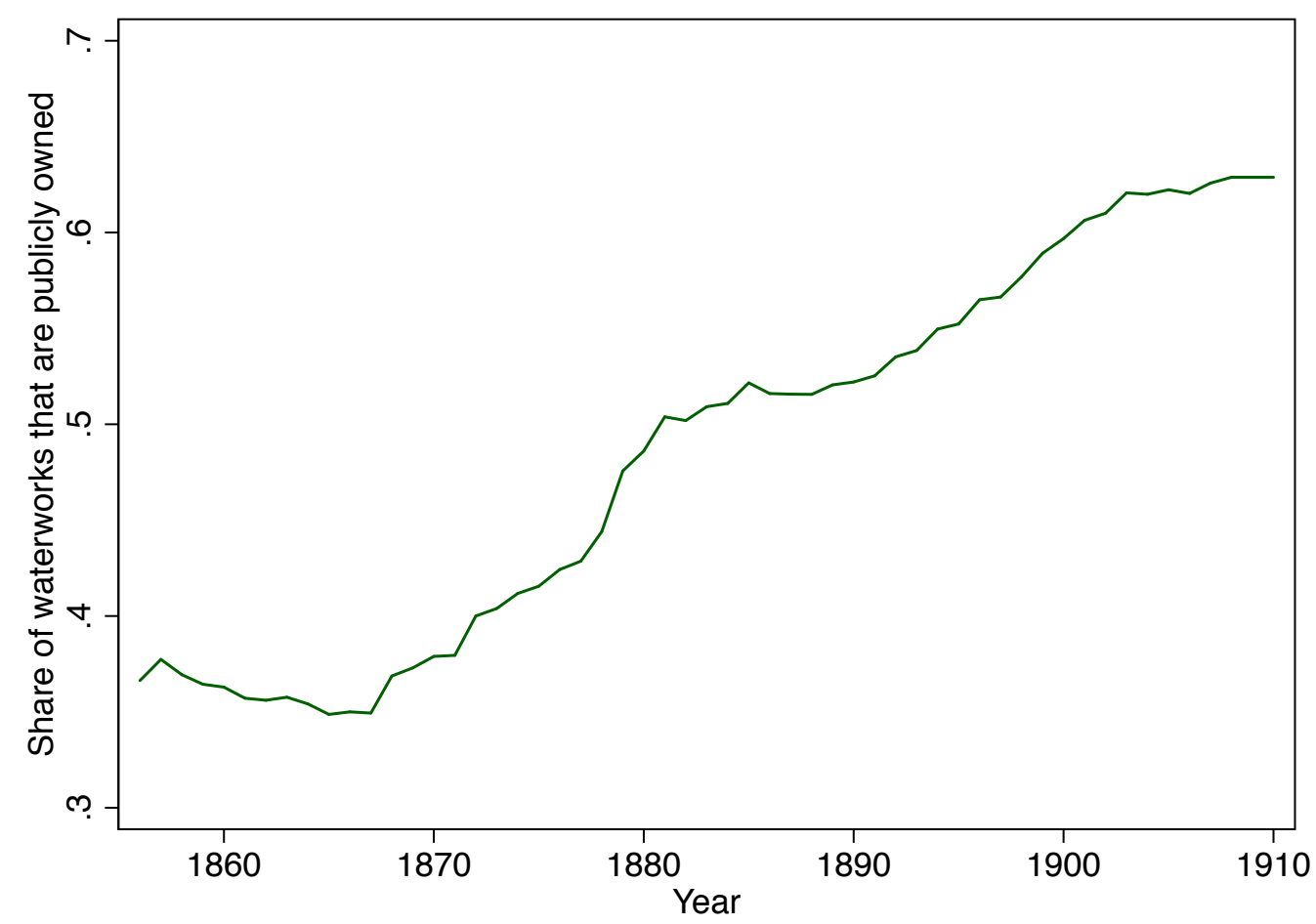

Notes: Public ownership share is simply the share of existing waterworks that are publicly owned. Thus, an increase in public ownership share can result from either the construction of a publicly owned waterworks or the municipalisation of an existing privately-owned waterworks. Ownership data and year built data are from The Water Works Directory and Statistics, 1907.

While the decision to municipalise was dictated by the preferences and concerns of local voters and politicians, pre-existing institutions and legal rules that varied over time and across municipalities meant that the decision to municipalise did not instantaneously result in a public take over. Instead, these institutions and laws introduced long and exogenously determined lags in the process of municipalisation. As we discuss below, British authorities enacted legislation in an effort to standardize the procedures surrounding municipal take overs, however, arbitration and long negotiations were an essential part of the process, and there was no guarantee of agreement at the end of such negotiations (Donald 1902; Silverthorne 1881; McCulloch, 2004). 
Three examples help illustrate just how long the delays could be. First, ten years after the Bridlington and Quay Water Co. Ltd was formed as a non-statutory company in 1865, a purchase clause was added to the company's application for statutory status, but the Bridlington and Quay Water Co. remained privately owned until 1899 (Charlesworth, 1912). Second, Birmingham's local government was empowered by an Act of 1851 to supply water for private and public uses and to purchase the existing company's works by agreement or arbitration after 12 months yet it took another 24 years for Birmingham to acquire the company. Third, the Bristol Water Company, established in 1846, continues to operate today despite attempts by the local council to purchase the works in 1882 and 1887. In contrast to the United States, the prevailing legal environment prevented local authorities from directly competing with private companies and the power of compulsory purchase was granted in only exceptional cases. (Thornton and Pearson, 2013).

Which institutions and laws mattered most in determining how quickly a particular company could be taken over? Aside from the specific acts of Parliament chartering individual companies, cities, and towns, four legal changes were particularly important. First, the Public Health Act of 1848, spearheaded by the prominent social reformer Edwin Chadwick, was the first Act to explicitly make local authorities responsible for ensuring that the provision of water was sufficient. While only compulsory in towns that were authorized to establish a local board of health, by 1858 the Public Health Act was applicable in 182 towns (Hamlin and Sheard, 1998). ${ }^{7}$ The Act provided local authorities with access to long-term loans and allowed them to take over private water companies if the companies agreed. Second, the 1866 Sanitary Act made local authorities responsible for sewers, water, and street cleaning; it also made house connection to a sewer compulsory. While the act also gave the Secretary of State power to bring proceedings against a local authority failing to ensure sufficient water was provided, this provision was rarely, if ever, enforced (Wohl, 1983: 113 and 155-6).

Third, and perhaps most important, was the 1875 Public Health Act, which consolidated all prior acts relating to public health. The act required all local authorities

\footnotetext{
${ }^{7}$ After the Local Government Act of 1858 , boards of health became local boards. With the Public Health Act of 1875, local boards became urban sanitary districts. After the 1894 Local Government Act they became county districts.
} 
(now designated "urban sanitary districts") to ensure adequate water supplies, gave detailed guidance on what local authorities had to do in terms of drainage, water supply, and sewage removal, and made oversight of these requirements the responsibility of the Local Government Board (Millward, 2013: 193; MacDonagh, 1977: 131). According to MacDonagh $(1977,158)$, the Public Health Act "represented a Napoleon-like codification of the great mass of uncoordinated legislation of the preceding forty years or more." A number of subsequent acts amended or extended the 1875 Public Health Act. For example, the 1878 Public Health (Water) Act clarified the duty to ensure clean water provision in rural sanitary districts. Another public health related measure in 1875 focused on artisans dwellings and empowered local authorities to destroy and replace unsanitary dwellings. ${ }^{8}$ The passage of the 1875 Public Health Act was followed by a wave of municipalisation, highlighting the importance of nationally imposed laws and institutions in shaping the actions of local governments.

Finally, the 1894 Local Government Act replaced the urban and rural sanitary districts established under the 1875 Public Health Act with urban and rural county districts falling under the jurisdiction of the district councils, as established in the 1888 Local Government Act (Ryde, 1894: xxix). The Act gave voice to more ratepayers by extending the powers and obligations of parishes, and expanded the power of parish councils, allowing them to serve as parochial committees to which rural county districts delegated powers allowed by the Public Health Acts. This included the power to require owners of occupied houses to ensure water was provided within a reasonable distance, and allowing them to report directly to the county council any concerns over the "insufficiency or unwholesomeness" of the existing water supply (Ryde, 1894: 72-73). As with the Public Health Act of 1875, the 1894 Local Government Act was followed by a spurt of municipalisations, again illustrating the significance of national laws in shaping the pace at which local governments were able to municipalise their water systems.

These institutions not only influenced the timing of municipalisation; they also gave it permanence. Once a private company was municipalised in Victorian Britain, it rarely, if ever, went back over the course of our sample period. While public water boards

\footnotetext{
${ }^{8}$ Most parts of the act were not directly applicable to metropolitan London because it did not have a single local authority as referenced in the act.
} 
were privatized during the later half of the twentieth century, none of the companies that were municipalised in our large sample switched back to being private before 1910 - the end of our study period.

\section{Typhoid fever as a proxy for water quality}

We use typhoid fever, a waterborne disease, as a proxy for water quality. We rely on typhoid fever fatality rates because direct measures of water quality (i.e. bacteria counts) are not available for this time period. Nevertheless, typhoid fever is an appropriate proxy for water quality because typhoid fever rates are highly correlated with the quality and extensiveness of water and sewerage systems, particularly during this time period (Cutler and Miller 2005; Beach et al. 2016). The relationship between deaths from typhoid fever and water quality results from the fact that typhoid fever was typically contracted by drinking water tainted by the faecal wastes of infected individuals. Thus, typhoid rates were higher in cities with inadequate filtration or sewage disposal.

This fact was not lost on contemporary observers on either side of the Atlantic. In 1879, Sir Richard Thorne, Principal Medical Officer to the Local Government Board,

first presented evidence that a typhoid outbreak in Caterham and Redhill was spread by contaminated water. ${ }^{9}$ From the 1880 s onwards, the British Medical Journal (BMJ) reports frequently on the close connection between contaminated water and typhoid fever. In 1895, the BMJ's editor, Ernest Hart, wrote an extended article on typhoid in which he made the case for sewage-contaminated water as the primary means of typhoid transmission. In the US, George Whipple, co-founder of the Harvard School of Public Health, argued, "A very low [typhoid] death rate indicates a pure water, and a very high rate, contaminated water." 10 Similarly, a report on water quality in New York City in 1912 stated "the death rate from typhoid fever is commonly taken as one index of the quality of a water supply." 11

\footnotetext{
${ }^{9}$ Published in Thorne (1879), p. 117-9.

${ }^{10}$ Whipple (1908), p. 228.

${ }^{11}$ Engineering News, May, 1913, p. 1087
} 
Of course, typhoid fever could be spread by other means, and typhoid fever was not the only waterborne disease that posed a threat to human health. For this reason, the New York report on water quality noted that typhoid fever might be an imperfect proxy for water quality. However, it has been widely shown that, prior to water treatment, nonwaterborne typhoid transmissions only accounted for a small fraction of total outbreaks (Troesken, 2004; Whipple 1908). Furthermore, as Beach et al. (2016) discuss, most milkborn epidemics (the second most prominent transmission mechanism after water) originated from the use of polluted water sources. It has also been documented that deaths from typhoid fever and deaths from other waterborne diseases (i.e. deaths from cholera or deaths due to diarrhoea) were highly correlated (Fuertes, 1897).

\section{Data}

Our analysis relies on the following pieces of information: current ownership (municipal or private), year the waterworks was built, ownership at the time the waterworks was built, and the year ownership changed (if applicable). This information was primarily obtained from the $27^{\text {th }}$ Water Works Directory and Statistics. ${ }^{12}$ The "Directory" was intended to be a comprehensive annual publication of all waterworks in Britain and Ireland, but it relied on waterworks staff completing and returning surveys. ${ }^{13}$ Accordingly, whenever possible, we crosschecked this information using two secondary sources (Silverthorne, 1884; Donald, 1902). ${ }^{14} \mathrm{We}$ obtain complete ownership and construction information for 563 of the 631 waterworks listed in these sources. Of those

\footnotetext{
${ }^{12}$ For some waterworks where the entry was not clear regarding prior ownership, this was checked using sources available via the web or through parliamentary papers.

${ }^{13}$ The first edition of the Directory was edited and published by Charles W. Hastings in 1881 as "Waterworks Statistics" and included information on 134 towns. Few copies of the earlier editions remain so details of the evolution of the publication are unclear, but secondary reviews suggest that the $27^{\text {th }}$ edition (published in 1907) used here provides a comprehensive and accurate coverage having received support from the British Association of Waterworks Engineers. Most entries include information on the owner/operator of the waterworks, date established, important Acts of Parliament, distance from London and population served; some entries also include detail on capital invested, water source, quality, and prices. The Directory sought to be comprehensive, so when a town receives its water from another town, the directory lists that town.

${ }^{14}$ The Victorian era saw the publication of many lists and directories, each with a specific focus. Arthur Silverthorne compiled the list of waterworks serving large towns largely to further his argument that it was time to reduce the water rates charged by local authorities. The Municipal Yearbook was edited by Robert Donald, editor of "The Municipal Journal", as a reference of the work undertaken by all local authorities.
} 
563 waterworks, 240 waterworks were publicly built and 323 were privately built. 127 of the 303 privately built waterworks were publicly acquired by 1907 .

Figure 2 plots the distribution of those acquisition dates. Acquisitions occur between 1847 and 1907. We do not observe acquisitions after 1907 because our waterworks data come from sources that were published in 1907. Given the slowdown in municipalisation of waterworks and of municipal spending more broadly (Millward and Sheard, 1995: 505), it is not likely that using a later directory would alter our results. ${ }^{15}$ The median acquisition occurs in 1883. Most acquisitions occur between two time periods 1870-1885 and 1895-1907. As noted above, the first of these periods coincides with the Public Health Act of 1875 while the second follows the 1894 Local Government Act. ${ }^{16}$

\section{Figure 2: Distribution of acquisition dates}

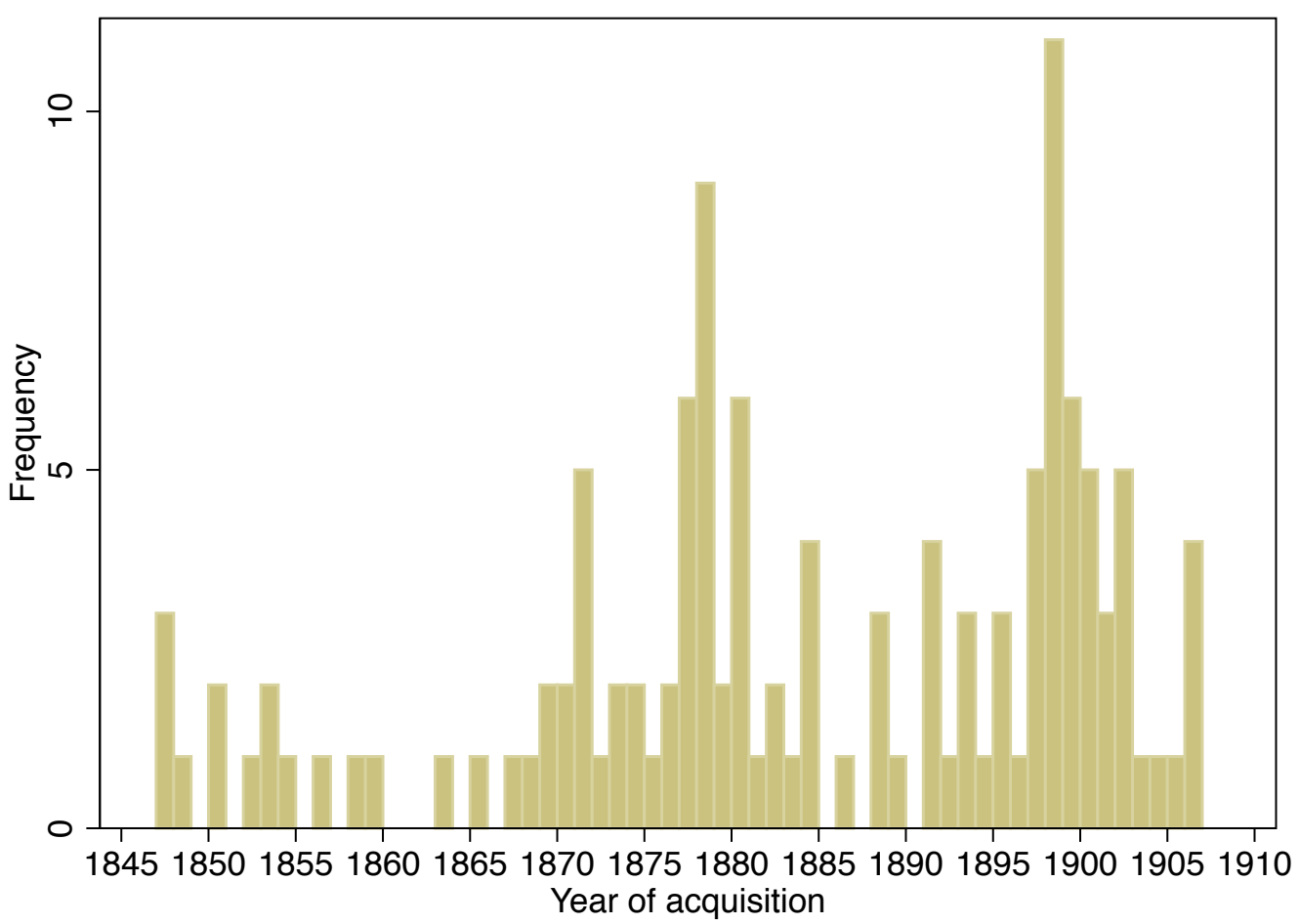

\footnotetext{
${ }^{15}$ Directories are also available for 1909-10 and 1911-12, but when we compared entries they appeared to be identical to the 1907 edition.

${ }^{16}$ This clustering of acquisitions around major legislation suggests that central government regulation played a role in driving local improvements in water supply and sanitation. However, the acts may have passed due to broader voter support for reform, as suggested by Hamlin (1988) who argues that, in practice, public health reformers in central government had few powers of enforcement and local sanitary improvements took place "despite the public health acts, not by using them" (58).
} 
Notes: Sample of 127 acquisitions represents the set of privately-built waterworks (with complete information) that were municipalised between 1845 and 1907. Data are from The Water Works Directory and Statistics, 1907.

Our mortality data come from annual reports of the Registrar General. As noted in Beach and Hanlon (2016) these data were the result of a large and coordinated effort to register every birth, marriage, and death in England and Wales. For every death, the body could not be legally disposed of unless the death was registered with the local official. The local official would record the age, gender, occupation, and cause of death of the deceased. The Registrar General's office tried to standardize cause-of-death classification by constructing and circulating disease nosologies and by providing local officials with standardized cause of death certificates. The Registrar General's annual reports tabulate causes of death for all districts within England and Wales. We transcribe mortality data for each district between 1869 and 1910. Our analysis begins in 1869, when typhoid fever (our proxy for water quality) is first listed as a cause of death in the Registrar's tabulations. Because the Registrar reports counts instead of rates, we obtain population from the 1851, 1861, 1871, 1881, 1891, 1901, and 1911 decennial censuses. By interpolating between census years we are able to transform counts into death rates per 10,000 .

We successfully link 327 of the 563 waterworks with complete information and 77 of the 127 waterworks that change ownership to mortality data from the Registrar General. Unsuccessful links occur for two reasons: 1) we have mortality data only for England and Wales but our waterworks data also include Scotland, Ireland, and the Channel Islands; and 2) because registration districts and our towns do not overlap neatly. ${ }^{17}$ The imperfect overlap between towns and registration districts means that a few waterworks supply more than one registration district and some districts receive water from more than one waterworks. Of the 447 registration districts that are linked to a waterworks, 312 receive water from only one waterworks. For the remaining 135 districts, 93 receive water from two waterworks and 42 receive water from more than two

\footnotetext{
${ }^{17} \mathrm{We}$ also exclude London because it is different to the provincial towns included in our sample, in so many ways: larger population, supplied by multiple water companies, significantly larger waterworks investment than all other towns, and it was initially exempt from most clauses in the 1875 Public Health Act. Under an Act of Parliament in 1902, London's eight companies were merged into one waterworks under the control of a newly created Metropolitan Water Board (Tynan, 2002).
} 
waterworks, likely reflecting that the registration district contains more than one reasonably sized town. We omit any registration district that is supplied by more than two waterworks. For the 93 districts that receive water from two sources, we link the district to the larger of the two waterworks, i.e. the larger town in that registration district.

Given that decisions regarding water works ownership are made at the local level, there may be concerns that we are picking up local characteristics that switching towns have in common. Figure 3, presents a map of each registration district in England and Wales. We draw on boundary files from 1901 and shade each registration district depending on whether that registration district can be linked to a waterworks, and if so whether that waterworks changes ownership or not. This map suggests that there is not a systematic geographic bias that determines whether a district appears in our sample or whether the waterworks changes ownership over our sample period.

Table 1 presents summary statistics for the waterworks that we are able to pair with mortality data. Specifically, we partition the linked sample into three groups waterworks that were publicly built (and never changed ownership), waterworks that were privately built but never changed ownership, and privately built waterworks that did change ownership. In Table 1 we see that privately built waterworks that change ownership are older. These waterworks also supply districts with larger populations. ${ }^{18}$ This fits with Hassan's finding that "larger towns tended to acquire control over water supplies first" (Hassan, 1985:539). ${ }^{19}$, Perhaps surprisingly, publicly built waterworks and privately built waterworks that don't change ownership are very similar in terms of age and the population of the districts that they serve.

\footnotetext{
${ }^{18}$ Note that the size of the district that the waterworks supplies is not the same as the size of the population served by the waterworks.

${ }^{19}$ Cutler and Miller $(2006,173)$ find the same pattern for the United States.
} 
Figure 3: Registration districts (in 1901) with matched waterworks

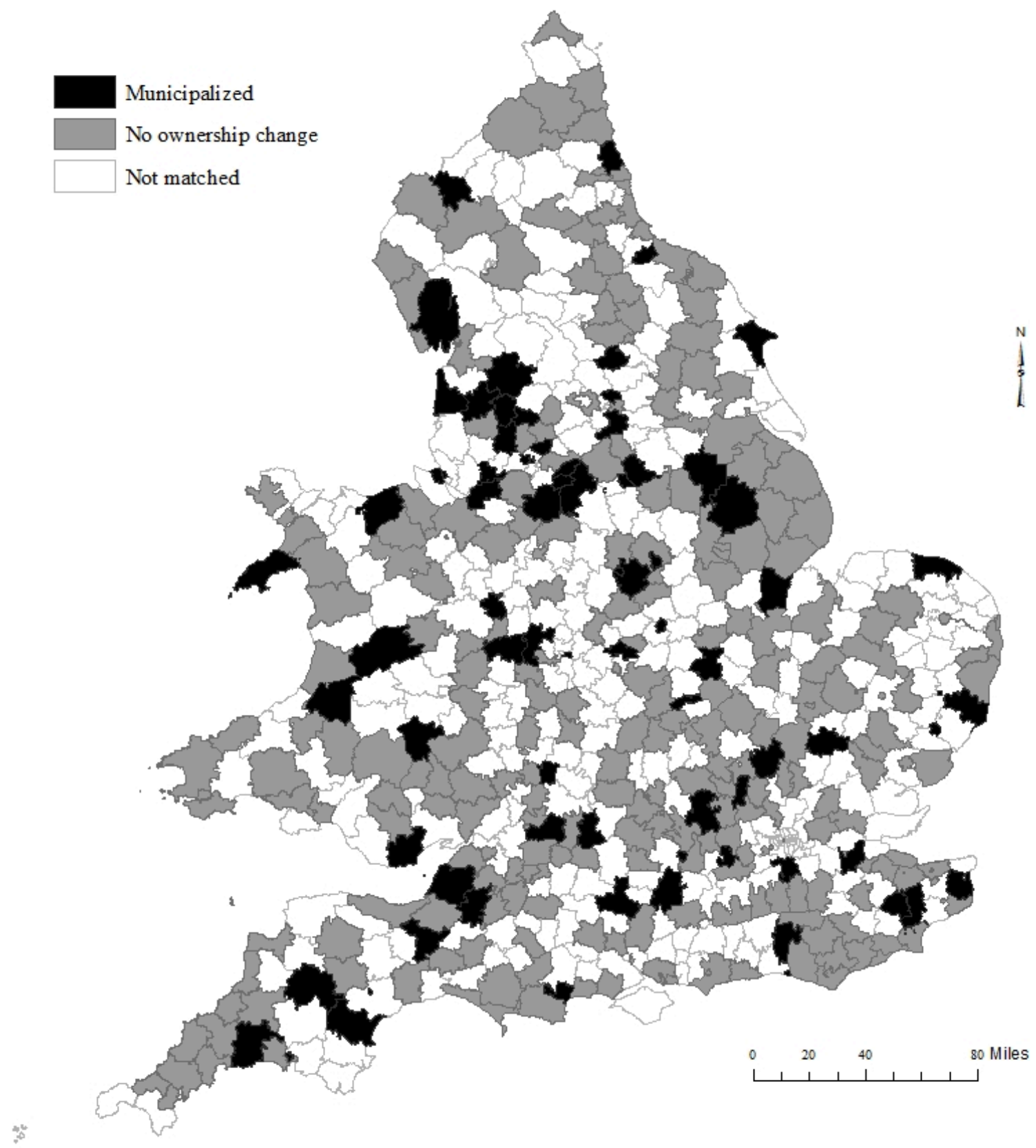

Notes: Boundary files are from Great Britain Historical GIS Project. Ownership information are from Data are from The Water Works Directory and Statistics, 1907. 
Table 1: Summary statistics

\begin{tabular}{lccc}
\hline \hline & Publicly built $\begin{array}{c}\text { Privately built } \\
\text { (no change in } \\
\text { ownership) }\end{array}$ & $\begin{array}{c}\text { Privately built } \\
\text { (changes } \\
\text { ownership) }\end{array}$ \\
\hline Mean year works was built & 1867 & 1866 & 1843 \\
Mean year of public acquisition & & & 1883 \\
Mean size of district "served" in 1871 & 28,942 & 29,760 & 55,494 \\
Mean population growth 1871-1911 & $19.12 \%$ & $22.21 \%$ & $35.98 \%$ \\
Number of works & 134 & 120 & 73 \\
\hline \hline
\end{tabular}

Notes: Served appears in quotes because the population of the district is not the same as the number of individuals within the district that receive their water from that waterworks, though of course the two numbers are correlated. Waterworks information comes from The Water Works Directory and Statistics, 1907. Population data come from the census.

One way to rationalize the patterns in Table 1 is that in large and fast growing districts with old waterworks, population growth strained the existing system, and for whatever reason, private companies were not able to respond to this growth by making investments to extend and improve the system. If so, this would have manifested itself in rising disease rates in the years prior to municipalisation and helped to spur the transition from (poorly functioning) private waterworks to municipal. In our formal regressions reported below, we find evidence consistent with this interpretation, and we adopt multiple strategies to control for the possibility that rising disease rates in the years prior to municipalisation might confound our estimates.

\section{Did Rising Disease Rates Spur Municipalisation?}

Before trying to identify the effects of municipalisation, we first explore the factors that gave rise to municipalisation. To do this, we estimate several probit models motivated by the following form: 


$$
\operatorname{Pr}\left(\text { Acquired }_{i t}=1 \mid X\right)=\Phi(X \beta)
$$

where "Acquired" will be an indicator variable that equals one if waterworks $i$ is municipalised in year $t$. We will also consider indicators for whether the waterworks is municipalised within one, two, three, four, or five years of t. Specifically, the "within one year" indicator equals 1 if the waterworks is municipalised in either year $t$ or year $t+1$. At the other end, the "Acquired within five years" indicator will equal 1 if the waterworks is municipalised in either year $t$, year $t+1$, year $t+2$, year $t+3$, year $t+4$, or year $t+5$. The vector $\mathrm{X}$ will include year fixed effects, which will tease out the explanatory effects of broader institutional changes that motivated general waves municipalisation (i.e. the public health act of 1875 and the 1894 local government act). In addition to these year fixed effects, we will also include the following district-level explanatory variables: the presence of a large typhoid epidemic, contemporaneous typhoid rates, average typhoid rates, age of the waterworks, and the population growth rate. Because publicly owned waterworks cannot be municipalised, all of our analysis is restricted to privately owned waterworks.

Results of this analysis are reported in Table 2. Each column corresponds to a different outcome variable (ranging from "Acquired this year" to "Acquired within five years"). Each row corresponds to a different explanatory variable, and all coefficients are marginal effects. First we consider the explanatory power of experiencing a large typhoid epidemic. One might be concerned that public officials are using epidemics as motivation for municipalisation and that there is something inherently different about they dynamics of epidemics that might be driving our results. To alleviate this concern, we construct an indicator that equals one if registration district $i$ experienced one of its five largest typhoid rates in year $t$. We then calculate the marginal effect to study the extent to which experiencing a large typhoid epidemic predicts municipalisation in the near future. Results indicate that experiencing a large typhoid epidemic does predict whether a privately owned waterworks is municipalised at any point in the following five years.

Next we consider as our primary explanatory variable of interest, the typhoid rate in year $t$. Here we see that a high typhoid rate in year $t$ is not a significant predictor of municipalisation in year t. However, when we expand the time horizon for acquisition, 
we see that high typhoid rates in year $\mathrm{t}$ are a meaningful and statistically significant predictor of municipalisation within the next two through five years. What is most interesting about these results is that the marginal effect increases as we increase the time horizon. This is consistent with two key components of the process of municipalisation: 1) that municipalisation was motivated by high typhoid rates and 2) that idiosyncratic delays broke down the link between typhoid rates and municipalisation. The third row of Table 2 presents more evidence consistent with these points. There we consider as our explanatory variable the average typhoid fatality rate over the last five years. The pattern in average typhoid rates is similar to that of $\ln$ (typhoid rates), however, the coefficient is slightly larger for average typhoid rates. Specifically, the results in Table 2 indicate that a 1 percent increase in $\ln$ (typhoid rate) in year $t$ increased the likelihood of municipalisation in year $t$ by 0.3 percent and the likelihood of municipalisation within the next five years by 1.1 percent. For $\ln$ (average typhoid rate) the coefficients are 0.4 percent in year $\mathrm{t}$ and 1.3 percent for municipalisation within the next five years. Of course, given the size of the standard errors, we cannot reject that these estimates are different from each other, so we interpret these differences as suggestive.

The remainder of our analysis is motivated by the differences between waterworks that change ownership (relative to those that do not change ownership) that we observed in Table 1. In the fourth column of Table 2 we consider the explanatory power of the age of the waterworks. There we see that each year increase in the age of the waterworks is associated with a highly significant 0.01 percent increase in the likelihood of municipalisation. Next we consider the role of population change. Specifically, we consider the percentage change in population over the last five years. ${ }^{20}$ Results from this specification indicate that experiencing a 10 percent increase in population between year $t-5$ and year $t$ increases the likelihood of municipalisation in year $t$ by 0.3 percent and increases the likelihood of municipalisation within the next five years by 0.9 percent. Together, the final three columns are consistent with the hypothesis laid out above: the aging infrastructure of privately owned waterworks was strained during periods of population growth. This manifested in higher typhoid rates, which together motivated municipalisation. As we discuss below, publicly owned firms were better equipped to

\footnotetext{
${ }^{20}$ Note that intercensal populations are inferred via interpolation.
} 
deal with these issues as public firms were able to borrow more cheaply than private firms, which in turn made necessary infrastructure investments feasible.

\section{Table 2: Marginal effects of district-level characteristics and the likelihood of} municipalisation in the near future

\begin{tabular}{|c|c|c|c|c|c|c|}
\hline & $\begin{array}{c}\text { Acquires this } \\
\text { year }\end{array}$ & $\begin{array}{c}\text { Aquires } \\
\text { within one } \\
\text { year }\end{array}$ & $\begin{array}{c}\text { Acquires } \\
\text { within two } \\
\text { years }\end{array}$ & $\begin{array}{c}\text { Acquires } \\
\text { within three } \\
\text { years }\end{array}$ & $\begin{array}{c}\text { Acquires } \\
\text { within four } \\
\text { years }\end{array}$ & $\begin{array}{c}\text { Acquires } \\
\text { within five } \\
\text { years }\end{array}$ \\
\hline Experiencing a top-5 epidemic & $\begin{array}{l}-0.0013 \\
(0.0040)\end{array}$ & $\begin{array}{l}-0.0025 \\
(0.0048)\end{array}$ & $\begin{array}{l}-0.0023 \\
(0.0055)\end{array}$ & $\begin{array}{c}0.001 \\
(0.0054)\end{array}$ & $\begin{array}{c}0.0018 \\
(0.0061)\end{array}$ & $\begin{array}{c}0.0052 \\
(0.0062)\end{array}$ \\
\hline $\ln$ (Typhoid fatality rate) & $\begin{array}{c}0.0032 \\
(0.0020)\end{array}$ & $\begin{array}{l}0.0050^{*} \\
(0.0026)\end{array}$ & $\begin{array}{l}0.0071 * * \\
(0.0035)\end{array}$ & $\begin{array}{c}0.0095^{* *} \\
(0.0041)\end{array}$ & $\begin{array}{c}0.0105 * * \\
(0.0049)\end{array}$ & $\begin{array}{c}0.0111^{*} \\
(0.0057)\end{array}$ \\
\hline $\ln$ (Avg typhoid fatality rate past five years) & $\begin{array}{c}0.0042 * * \\
(0.0018)\end{array}$ & $\begin{array}{c}0.0070 * * \\
(0.0029)\end{array}$ & $\begin{array}{l}0.0092 * * \\
(0.0039)\end{array}$ & $\begin{array}{c}0.0108 * * \\
(0.0049)\end{array}$ & $\begin{array}{c}0.0124 * * \\
(0.0061)\end{array}$ & $\begin{array}{l}0.0130 * \\
(0.0073)\end{array}$ \\
\hline Age of waterworks & $\begin{array}{c}0.0001 * * * \\
(0.0000)\end{array}$ & $\begin{array}{c}0.0001 * * * \\
(0.0000)\end{array}$ & $\begin{array}{c}0.0001 * * * \\
(0.0000)\end{array}$ & $\begin{array}{c}0.0002 * * * \\
(0.0001)\end{array}$ & $\begin{array}{c}0.0002 * * * \\
(0.0001)\end{array}$ & $\begin{array}{c}0.0002 * * * \\
(0.0001)\end{array}$ \\
\hline Percent change in population over the last five years & $\begin{array}{c}0.0259 * * \\
(0.0104)\end{array}$ & $\begin{array}{c}0.0421 * * \\
(0.0167)\end{array}$ & $\begin{array}{c}0.0572 * * \\
(0.0225)\end{array}$ & $\begin{array}{c}0.0716 * * * \\
(0.0279)\end{array}$ & $\begin{array}{c}0.0883 * * \\
(0.0348)\end{array}$ & $\begin{array}{c}0.0944 * * \\
(0.0441)\end{array}$ \\
\hline
\end{tabular}

Standard errors (clustered at the waterworks level) in parentheses.

$$
* \mathrm{p}<.1 * * \mathrm{p}<.05 * * * \mathrm{p}<.01
$$

Notes: Death rates are measured as deaths per 10,000 persons. Mortality data are from annual registrar general reports. Top-5 epidemic is an indicator equal to one if the district experiences one of its five largest typhoid death rates in year t. Waterworks acquisition and age are from The Water Works Directory and Statistics, 1907.

\section{Estimating the Effects of Municipalisation on Typhoid: Main Results}

\subsection{Graphical evidence}

As discussed in Section 2, municipalities faced a number of bureaucratic hurdles that provide variation in the timing and persistence of municipalisation. Exploiting this variation, Figure 4 visually displays our main result. Figure 4 is a binned scatter plot, where each bin corresponds to normalized death rates near the time of municipalisation. The death rates were normalized by regressing either the log of the typhoid fatality rate (panel a) or the log of the non-waterborne disease fatality rate (panel b) on district and year fixed effects. ${ }^{21}$ Because acquisitions occur at different points in time, we include year fixed effects to control for general trends. We include district fixed effects to

\footnotetext{
${ }^{21}$ We construct a measure of non-waterborne deaths by aggregating deaths from: smallpox, measles, scarlet fever, typhus, whooping cough, diphtheria, and violence.
} 
normalize the data across registration districts. The goal of Figure 4 is to illustrate how mortality rates evolved before and after acquisition. Thus, we estimate two nonparametric lines that correspond to the pre and post intervention periods. ${ }^{22} \mathrm{We}$ use the year after acquisition as the "intervention" date as it is highly likely that there will be a delay between when the acquisition occurs and when the mortality statistics reflect the effect of that intervention. This delay results from two channels. First, we are using annual data and acquisition can occur at any point during the year and so acquisition dates are inherently noisy. Second, the types of investments a municipality is likely to make (e.g. extending water mains, adopting filtration technologies) do not occur instantaneously. Failing to account for these delays decreases the precision of our estimates.

The first panel of Figure 4 has two notable features. First, typhoid rates begin rising about 10 years prior to municipalisation; earlier than that, the data are noisy and do not exhibit any clear trend. The fact that typhoid fatality rates in these cities were increasing relative to the rest of England ten years prior to municipalisation likely served as one motivation for municipalisation. It also has implications for our empirical analysis - failure to control for these trends will likely confound the results. The second pattern is that typhoid rates fall sharply following municipalisation. Specifically, it appears that typhoid rates fell by a statistically significant 12 percent in the year after municipalisation, which suggests that public acquisition had a meaningful effect on the local disease environment.

\footnotetext{
${ }^{22}$ The non-parametric lines are estimated using all of the data, not just the binned averages.
} 
Figure 4: Binned scatter plot of normalized $\ln ($ death rates) near the time of public acquisition
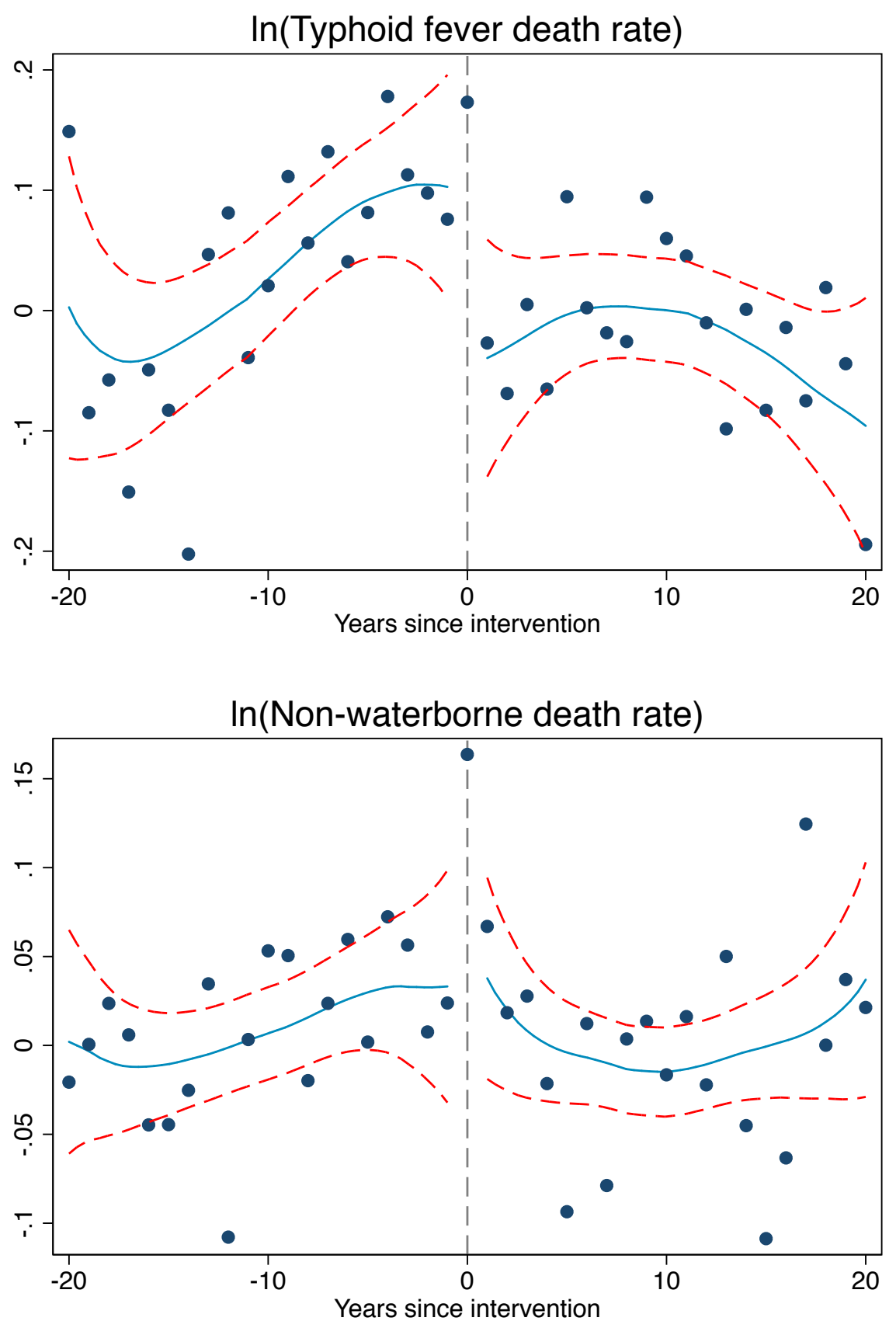

Notes: Local polynomial estimates constructed as via local linear regression with a four-year bandwidth. Intervention date corresponds to the year after public acquisition of the waterworks. Observations correspond to average normalized mortality rates, which are obtained by simply regressing the $\ln$ (death rate) on city and year fixed effects. Non-waterborne deaths include: smallpox, measles, scarlet fever, typhus, whooping cough, diphtheria, and violence. Mortality data are from annual registrar general reports. Acquisition data are from The Water Works Directory and Statistics, 1907. 
The second panel of Figure 4 serves as a placebo test by repeating our analysis to explore how municipalisation affected deaths from seven non-waterborne causes: smallpox, measles, scarlet fever, typhus, whooping cough, diphtheria, and violence. If deaths from non-waterborne causes were significantly affected by municipalisation then this would cast doubt on whether the typhoid mortality rate was falling because of a change in ownership (and any subsequent investments in water purification technologies or sewers that might accompany that change in ownership). For example, one might be concerned that an omitted factor (e.g. an increase in state capacity) 1) allowed the government to more effectively control the local disease environment and 2) provided the means for the government to municipalise its waterworks. Another possibility addressed in this figure is mean reversion. If it was merely mean reversion in typhoid rates driving the results above, one would not expect to observe the same patterns in other diseases.

It should be noted, however, that this placebo test is biased towards finding a result. Specifically, it has been shown that historically improved water quality reduced deaths not only from waterborne diseases such as typhoid, but also deaths from nonwaterborne causes as well (Cutler and Miller, 2005; Ferrie and Troesken, 2008). In other words, a response in the non-waterborne death rate could be evidence that is consistent with municipalisation. Nevertheless, one expects the effects on waterborne nonwaterborne diseases to have been relatively small and statistically noisy. And that is precisely what the data suggest: the non-waterborne disease rate exhibits a mild upward trend prior to municipalisation, and while there is a flattening in this trend post municipalisation there is no sharp or statistically meaningful break in trend. To the extent that these seven non-waterborne diseases would reflect any relevant confounding factor, these patterns suggest the fall in the typhoid fever fatality rate was causally related to municipalisation. Formal regressions in the following section as well as Section 8 extend and confirm this claim.

\subsection{Regression analysis}

Next we employ a differences-in-differences strategy to measure the extent to which the public acquisition of a privately built waterworks affects deaths from waterborne diseases. Specifically, we estimate variations of the following equation: 


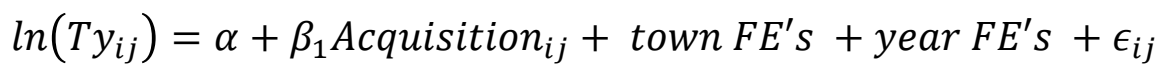

where $T y_{i j}$ refers to the typhoid fatality rate (per 10,000) in town $\mathrm{i}$ during year $\mathrm{j}$. The

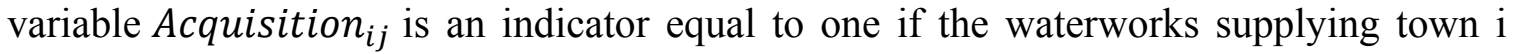
was municipalised at least one year before year $\mathrm{j}$. As previously mentioned, we use the year after acquisition as the "treatment" date as there will likely be a delay between acquisition and treatment. All regressions also include town and year fixed effects. Because treatment occurs at the waterworks and waterworks can supply more than one town we cluster standard errors at the waterworks level.

Table 3: The effect of public acquisition on mortality rates

\begin{tabular}{|c|c|c|c|c|c|c|}
\hline & \multicolumn{3}{|c|}{$\ln$ (Typhoid death rate) } & \multicolumn{3}{|c|}{$\ln ($ Non-waterborne death rate) } \\
\hline & $(1)$ & $(2)$ & $(3)$ & $(4)$ & $(5)$ & $(6)$ \\
\hline Post acquisition indicator & $\begin{array}{c}-0.0425 \\
(0.0654)\end{array}$ & $\begin{array}{c}-0.192 * * \\
(0.0746)\end{array}$ & $\begin{array}{l}-0.169 * * \\
(0.0763)\end{array}$ & $\begin{array}{c}-0.0018 \\
(0.0416)\end{array}$ & $\begin{array}{c}-0.0536 \\
(0.0618)\end{array}$ & $\begin{array}{l}-0.0295 \\
(0.0511)\end{array}$ \\
\hline Pre-acquisition time trend & & $\begin{array}{c}0.0225^{* *} \\
(0.0089)\end{array}$ & $\begin{array}{c}0.0215^{* *} \\
(0.0090)\end{array}$ & & $\begin{array}{c}0.0076^{*} \\
(0.0046)\end{array}$ & $\begin{array}{c}0.0065 \\
(0.0042)\end{array}$ \\
\hline Post-acquisition time trend & & & $\begin{array}{l}-0.00192 \\
(0.0036)\end{array}$ & & & $\begin{array}{r}-0.0019 \\
(0.0017)\end{array}$ \\
\hline City fixed effects & $\mathrm{Y}$ & $\mathrm{Y}$ & $\mathrm{Y}$ & $\mathrm{Y}$ & $\mathrm{Y}$ & $\mathrm{Y}$ \\
\hline Year fixed effects & $\mathrm{Y}$ & $\mathrm{Y}$ & $\mathrm{Y}$ & $\mathrm{Y}$ & $\mathrm{Y}$ & $\mathrm{Y}$ \\
\hline R-squared & 0.524 & 0.524 & 0.525 & 0.520 & 0.520 & 0.521 \\
\hline Observations & 11,513 & 11,513 & 11,481 & 13,692 & 13,692 & 13,650 \\
\hline
\end{tabular}

Standard errors (clustered at the waterworks level) in parentheses.

$* \mathrm{p}<.1 * * \mathrm{p}<.05 * * * \mathrm{p}<.01$

Notes: Death rates are measured as deaths per 10,000 persons. The non-waterborne death rate includes deaths from smallpox, measles, scarlet fever, typhus, whooping cough, diphtheria, and violence. The pretrend turns on ten years prior to acquisition and runs until municipalisation. The post-acquisition time trend turns on once municipalisation occurs. Mortality data are from annual registrar general reports. Acquisition data are from The Water Works Directory and Statistics, 1907.

The first column of Table 3 presents results from estimating equation (2). In this column we find a negative but insignificant relationship between municipalisation and the typhoid fever death rate. However, as shown in Figure 4, local typhoid death rates were increasing in the ten years prior to municipalisation, and so the appropriate specification should include a pre-acquisition time trend. In the second column we add include a linear time trend beginning 10 years prior to acquisition. Once the pre-trend is 
included, we find that the typhoid fever fatality rate fell by about 19 percent following municipalisation. In the third column we add a post-acquisition time trend to ease any concerns about mean reversion and find similar results. As a placebo, columns 4 through 6 repeat this analysis using deaths from non-waterborne causes as the outcome variable. Consistent with Figure 4, we find small, negative, and insignificant results for each specification.

In Table 4 we test the sensitivity of our results to our choice of a pre-trend. Specifically, we use pre-trends beginning 5, 10, 15, and 20 years prior to public acquisition. Results are qualitatively consistent across specifications, but the results are strongest when we use a shorter pre-trend. This makes sense because if high disease rates are a motivation for municipalisation, then a town is less likely to allow high disease rates to persist for 15 or 20 years. More directly, it is clear from Figure 4 that shorter pretrends, those around 10 ten years, fit the data best.

Table 4: Sensitivity to choice of pre-trend

\begin{tabular}{lcccc}
\hline \hline & $(1)$ & $(2)$ & $(3)$ & $(4)$ \\
\hline Post acquisition indicator & $-0.182^{* *}$ & $-0.169^{* *}$ & $-0.147^{*}$ & -0.119 \\
& $(0.0891)$ & $(0.0763)$ & $(0.0750)$ & $(0.0728)$ \\
& & & & \\
Pre-acquisition time trend & $0.0379^{*}$ & $0.0215^{* *}$ & $0.0148^{* *}$ & $0.0103^{* *}$ \\
& $(0.0208)$ & $(0.0090)$ & $(0.0059)$ & $(0.0046)$ \\
& & & & \\
Post-acquisition time trend & -0.00227 & -0.00192 & -0.00177 & -0.00182 \\
& $(0.0036)$ & $(0.0036)$ & $(0.0036)$ & $(0.0036)$ \\
& & & & \\
Length of pre-trend & 5 years & 10 years & 15 years & 20 years \\
& & & & \\
City fixed effects & $\mathrm{Y}$ & $\mathrm{Y}$ & $\mathrm{Y}$ & $\mathrm{Y}$ \\
Year fixed effects & $\mathrm{Y}$ & $\mathrm{Y}$ & $\mathrm{Y}$ & $\mathrm{Y}$ \\
& & & & \\
R-squared & 0.524 & 0.524 & 0.525 & 0.525 \\
Observations & 11,481 & 11,481 & 11,481 & 11,481 \\
\hline \hline
\end{tabular}

Standard errors (clustered at the waterworks level) in parentheses. $* \mathrm{p}<.1 * * \mathrm{p}<.05 * * * \mathrm{p}<.01$

Notes: Death rates are measured as deaths per 10,000 persons. The non-waterborne death rate includes deaths from smallpox, measles, scarlet fever, typhus, whooping cough, diphtheria, and violence. The pretrend runs until municipalisation. The post-acquisition time trend turns on once municipalisation occurs. Mortality data are from annual registrar general reports. Acquisition data are from The Water Works Directory and Statistics, 1907 
In Table 1 and Table 2 we reported some evidence that age of the waterworks and population growth over the last five years served as a motivation for municipalisation. Our interpretation was that infrastructure was likely strained for older waterworks that were experiencing population growth, which in turn manifested in higher typhoid rates. To explore this possibility further, we first interact the municipalisation indicator with a normalized "age of waterworks at the time of municipalisation" variable. For waterworks that change ownership, the average waterworks was 37.9 years old at the time of acquisition. Thus, our normalized age is the actual age of the waterworks at the time of municipalisation minus the average age. Table 5 presents the result of this interaction. Results indicate that, for the average waterworks typhoid fever rates fell by 19 percent following municipalisation, even allowing for differential effects by age. That said, for relatively new waterworks municipalisation had a relatively small effect. For example, for waterworks that were 15 years newer than the average, or one half of a standard deviation, taking the linear combination of the Post acquisition indicator and its interaction with age of waterworks, the magnitude falls to 9 percent reduction in typhoid fever rates and is no longer statistically significant.

In Table 6 we interact our acquisition indicator with the normalized population growth rate. For waterworks that change ownership, the average population growth rate in the five years prior to acquisition was 5 percent, and so our normalized population growth rate is simply the actual growth rate minus 0.05 . Results in Table 6 indicate that, for the average waterworks, typhoid rates fell by about 13 percent following municipalisation. For each percentage point increase in the population growth rate, however, the typhoid death rate fell by an additional 0.136 percent. This suggests that waterworks with abnormally high population growth are not driving our results. 
Table 5: Interacting municipalisation with age of waterworks

\begin{tabular}{lccc}
\hline \hline & $(1)$ & $(2)$ & $(3)$ \\
\hline & & & \\
Post acquisition indicator & -0.0508 & $-0.208^{* * *}$ & $-0.185^{* *}$ \\
& $(0.0638)$ & $(0.0702)$ & $(0.0755)$ \\
& & & \\
Post acquisition X Age of waterworks (relative to the mean) & -0.00592 & -0.00606 & -0.00606 \\
& $(0.0049)$ & $(0.0047)$ & $(0.0046)$ \\
& & & \\
Pre-acquisition time trend & & $0.0235^{* * *}$ & $0.0225^{* *}$ \\
& & $(0.0089)$ & $(0.0090)$ \\
& & & -0.00190 \\
Post-acquisition time trend & & & $(0.0036)$ \\
& & & $Y$ \\
City fixed effects & & $\mathrm{Y}$ & $\mathrm{Y}$ \\
Year fixed effects & $\mathrm{Y}$ & $\mathrm{Y}$ & \\
& & & \\
R-squared & & & \\
Observations & 0.525 & 0.525 & 0.526 \\
\hline \hline
\end{tabular}

Standard errors (clustered at the waterworks level) in parentheses.

$* \mathrm{p}<.1 * * \mathrm{p}<.05 * * * \mathrm{p}<.01$

Mean age of waterworks at time of acquisition is 37.9 years.

Notes: Death rates are measured as deaths per 10,000 persons. The non-waterborne death rate includes deaths from smallpox, measles, scarlet fever, typhus, whooping cough, diphtheria, and violence. The pretrend turns on ten years prior to acquisition and runs until municipalisation. The post-acquisition time trend turns on once municipalisation occurs. Mortality data are from annual registrar general reports. Acquisition data are from The Water Works Directory and Statistics, 1907.

\section{Table 6: Interacting municipalisation with population growth}

\begin{tabular}{|c|c|c|c|}
\hline & $\overline{(1)}$ & $\overline{(2)}$ & $\overline{(3)}$ \\
\hline Post acquisition indicator & $\begin{array}{c}-0.0392 \\
(0.0654)\end{array}$ & $\begin{array}{c}-0.197 * * * \\
(0.0746)\end{array}$ & $\begin{array}{c}-0.128^{*} \\
(0.0764)\end{array}$ \\
\hline Post acquisition X Population growth (relative to the mean) & $\begin{array}{c}-0.0646 \\
(0.7025)\end{array}$ & $\begin{array}{c}-0.126 \\
(0.6753)\end{array}$ & $\begin{array}{c}-0.137 \\
(0.6570)\end{array}$ \\
\hline Pre-acquisition time trend & & $\begin{array}{c}0.0238^{* * *} \\
(0.0089)\end{array}$ & $\begin{array}{l}0.0211 * * \\
(0.0091)\end{array}$ \\
\hline Post-acquisition time trend & & & $\begin{array}{l}-0.00568 \\
(0.0042)\end{array}$ \\
\hline City fixed effects & Y & $\mathrm{Y}$ & $\mathrm{Y}$ \\
\hline Year fixed effects & $\mathrm{Y}$ & $\mathrm{Y}$ & Y \\
\hline $\begin{array}{l}\text { R-squared } \\
\text { Observations }\end{array}$ & $\begin{array}{l}0.518 \\
11133\end{array}$ & $\begin{array}{l}0.518 \\
11.133\end{array}$ & $\begin{array}{c}0.519 \\
11.101\end{array}$ \\
\hline
\end{tabular}


Standard errors (clustered at the waterworks level) in parentheses.

$* \mathrm{p}<.1 * * \mathrm{p}<.05 * * * \mathrm{p}<.01$

Mean population growth (in the five years prior to acquisition) was 5 percent.

Notes: Death rates are measured as deaths per 10,000 persons. The non-waterborne death rate includes deaths from smallpox, measles, scarlet fever, typhus, whooping cough, diphtheria, and violence. The pretrend turns on ten years prior to acquisition and runs until municipalisation. The post-acquisition time trend turns on once municipalisation occurs. Mortality data are from annual registrar general reports. Acquisition data are from The Water Works Directory and Statistics, 1907.

\section{Placebo Tests}

Thus far our placebo tests have used non-waterborne deaths collectively as the dependent variable. Part of our motivation for aggregating each of the death categories is that many of causes of death were not prominent killers at the time (e.g. smallpox). As a result, when we decompose non-waterborne deaths and compute the $\ln$ (death rate) in any given year we observe several undefined values for some causes of death. Nevertheless, in Table 7, we present results from our preferred specification (including pre and post acquisition time trends) taking each non-waterborne cause of death as our outcome variable. We find no statistically-significant evidence that municipalisation affected deaths from smallpox, measles, scarlet fever, whooping cough, diphtheria, or violence. Typhus, the one cause of death that is affected by municipalisation at the 10 percent level, appears to be positively affected. Furthermore, there is no consistent statistically significant evidence that these death rates were falling prior to municipalisation, which increases our confidence that the observed fall in the typhoid fever fatality rate resulted from municipalisation not from a broader change that may have simultaneously made municipalisation feasible and resulted in other public health improvements. 


\section{Table 7: Decomposed effect of public acquisition on $\ln ($ non-waterborne mortality} rates)

\begin{tabular}{|c|c|c|c|c|c|c|c|}
\hline & $\begin{array}{c}\text { Smallpox } \\
\text { (1) }\end{array}$ & $\begin{array}{c}\text { Measles } \\
\text { (2) }\end{array}$ & $\begin{array}{c}\text { Scarlet } \\
\text { fever } \\
\text { (3) }\end{array}$ & $\begin{array}{c}\text { Typhus } \\
\text { (4) }\end{array}$ & $\begin{array}{l}\text { Whooping } \\
\text { cough } \\
(5)\end{array}$ & $\begin{array}{c}\text { Diphtheria } \\
\text { (6) }\end{array}$ & $\begin{array}{c}\text { Violence } \\
\text { (7) }\end{array}$ \\
\hline Post acquisition indicator & $\begin{array}{c}-0.127 \\
(0.2842)\end{array}$ & $\begin{array}{c}-0.0827 \\
(0.1024)\end{array}$ & $\begin{array}{c}-0.0832 \\
(0.1091)\end{array}$ & $\begin{array}{c}0.221 * \\
(0.1261)\end{array}$ & $\begin{array}{c}0.0329 \\
(0.0706)\end{array}$ & $\begin{array}{l}-0.0933 \\
(0.1100)\end{array}$ & $\begin{array}{c}-0.0335 \\
(0.0517)\end{array}$ \\
\hline Pre-acquisition time trend & $\begin{array}{l}0.0517^{*} \\
(0.0309)\end{array}$ & $\begin{array}{c}0.0127 \\
(0.0116)\end{array}$ & $\begin{array}{c}0.0158 \\
(0.0110)\end{array}$ & $\begin{array}{l}-0.0267 \\
(0.0193)\end{array}$ & $\begin{array}{l}-0.00503 \\
(0.0075)\end{array}$ & $\begin{array}{c}0.0125 \\
(0.0117)\end{array}$ & $\begin{array}{l}0.00583 \\
(0.0045)\end{array}$ \\
\hline Post-acquisition time trend & $\begin{array}{c}-0.0269 * * \\
(0.0105)\end{array}$ & $\begin{array}{c}0.0000707 \\
(0.0029)\end{array}$ & $\begin{array}{c}-0.0153 * * * \\
(0.0043)\end{array}$ & $\begin{array}{c}-0.0406 * * * \\
(0.0116)\end{array}$ & $\begin{array}{c}-0.00585^{* *} \\
(0.0023)\end{array}$ & $\begin{array}{l}0.00510 \\
(0.0043)\end{array}$ & $\begin{array}{l}-0.00119 \\
(0.0018)\end{array}$ \\
\hline P-value testing difference in trends & 0.00715 & 0.306 & 0.00742 & 0.507 & 0.919 & 0.544 & 0.182 \\
\hline City fixed effects & $\mathrm{Y}$ & $\mathrm{Y}$ & $\mathrm{Y}$ & $\mathrm{Y}$ & Y & $\mathrm{Y}$ & $\mathrm{Y}$ \\
\hline Year fixed effects & $\mathrm{Y}$ & $\mathrm{Y}$ & Y & $\mathrm{Y}$ & $\mathrm{Y}$ & Y & $\mathrm{Y}$ \\
\hline R-squared & 0.479 & 0.180 & 0.488 & 0.634 & 0.199 & 0.164 & 0.401 \\
\hline Observations & 2,539 & 10,342 & 10,312 & 2,899 & 12,169 & 11,468 & 13,625 \\
\hline
\end{tabular}

Standard errors (clustered at the waterworks level) in parentheses.

$$
* \mathrm{p}<.1 * * \mathrm{p}<.05 * * * \mathrm{p}<.01
$$

Notes: Death rates are measured as deaths per 10,000 persons. The non-waterborne death rate includes deaths from smallpox, measles, scarlet fever, typhus, whooping cough, diphtheria, and violence. The pretrend turns on ten years prior to acquisition and runs until municipalisation. The post-acquisition time trend turns on once municipalisation occurs. Mortality data are from annual registrar general reports. Acquisition data are from The Water Works Directory and Statistics, 1907.

For each cause, we also test whether the pre and post trends are different. These results also appear in Table 7. Results of this test indicate that the change in trends for smallpox and scarlet fever was, in fact, statistically significant. For all remaining causes, however, we fail to reject the hypothesis that the pre and post trends are the same. These changes might well result from the fact that purifying water had diffuse health effects (as discussed above) but it is also possible that we have not fully eliminated all potential confounders. We address this possibility in Table 8 . There, we repeat our main analysis adding non-waterborne diseases as controls. In the first column we control for the log of the smallpox and scarlet fever death rate, the two diseases where the post-trend was significantly smaller than the pre-trend. In the second column our control diseases are three of the largest non-waterborne causes of death - whooping cough, scarlet fever, and measles. In the third column we control for all seven non-waterborne causes of death. Our results are largely unaffected by the inclusion of any of these controls. In columns 4 through six we take repeat this analysis in levels instead of logs and find similar results. In one specification (column four) the coefficient on the public acquisition dummy is 
only significant at the 13 percent level, but the magnitude is similar across all three specifications.

Table 8: The effect of municipalisation on waterborne deaths controlling for other causes of death

\begin{tabular}{|c|c|c|c|c|c|c|}
\hline & \multicolumn{3}{|c|}{$\ln$ (Typhoid death rate) } & \multicolumn{3}{|c|}{ Typhoid death rate } \\
\hline & $(1)$ & $(2)$ & (3) & (4) & $(5)$ & $(6)$ \\
\hline Post acquisition indicator & $\begin{array}{l}-0.188 * * \\
(0.0774)\end{array}$ & $\begin{array}{l}-0.172 * * \\
(0.0749)\end{array}$ & $\begin{array}{l}-0.163 * * \\
(0.0730)\end{array}$ & $\begin{array}{c}-0.887 \\
(0.6213)\end{array}$ & $\begin{array}{l}-0.842 * \\
(0.5037)\end{array}$ & $\begin{array}{l}-0.698 * * \\
(0.3201)\end{array}$ \\
\hline Pre-acquisition time trend & $\begin{array}{c}0.0250^{* *} \\
(0.0105)\end{array}$ & $\begin{array}{c}0.0220^{* *} \\
(0.0090)\end{array}$ & $\begin{array}{c}0.0204^{* *} \\
(0.0089)\end{array}$ & $\begin{array}{c}0.0394 \\
(0.0265)\end{array}$ & $\begin{array}{c}0.0263 \\
(0.0367)\end{array}$ & $\begin{array}{c}0.0172 \\
(0.0394)\end{array}$ \\
\hline Post-acquisition time trend & $\begin{array}{c}0.000108 \\
(0.0036)\end{array}$ & $\begin{array}{l}-0.00170 \\
(0.0035)\end{array}$ & $\begin{array}{l}-0.00159 \\
(0.0035)\end{array}$ & $\begin{array}{c}-0.00186 \\
(0.0112)\end{array}$ & $\begin{array}{l}-0.00282 \\
(0.0123)\end{array}$ & $\begin{array}{l}0.00561 \\
(0.0071)\end{array}$ \\
\hline Non-waterborne controls & $\begin{array}{l}\text { Scarlet/ } \\
\text { Smallpox }\end{array}$ & $\begin{array}{c}\text { Whooping } \\
\text { cough/Scarlet } \\
\text { fever/Measles }\end{array}$ & $\begin{array}{l}\text { All non- } \\
\text { waterborne } \\
\text { causes }\end{array}$ & $\begin{array}{c}\text { Scarlet/ } \\
\text { Smallpox }\end{array}$ & $\begin{array}{l}\text { Whooping } \\
\text { cough/Scarlet } \\
\text { fever/Measles }\end{array}$ & $\begin{array}{l}\text { All non- } \\
\text { waterborne } \\
\text { causes }\end{array}$ \\
\hline City fixed effects & Y & Y & Y & Y & Y & Y \\
\hline Year fixed effects & Y & Y & Y & Y & $\mathrm{Y}$ & Y \\
\hline R-squared & 0.541 & 0.527 & 0.529 & 0.519 & 0.467 & 0.580 \\
\hline Observations & 9,440 & 11,336 & 11,481 & 13,652 & 13,652 & 13,652 \\
\hline
\end{tabular}

Standard errors (clustered at the waterworks level) in parentheses.

$* \mathrm{p}<.1 * * \mathrm{p}<.05 * * * \mathrm{p}<.01$

Notes: Death rates are measured as deaths per 10,000 persons. The "All non-waterborne causes" death rate includes deaths from smallpox, measles, scarlet fever, typhus, whooping cough, diphtheria, and violence. The pre-trend turns on ten years prior to acquisition and runs until municipalisation. The post-acquisition time trend turns on once municipalisation occurs. Mortality data are from annual registrar general reports. Acquisition data are from The Water Works Directory and Statistics, 1907.

\section{Epidemics and Mean Reversion}

In previous sections, we showed that typhoid fatality rates fell by about 19 percent following municipalisation. Although the decision to municipalise an existing waterworks clearly depend on (lagged) typhoid rates, our identification hinges on the fact that municipalisation cannot occur instantaneously. As discussed in Section 2, legislators face a number of barriers that delayed the process of municipalisation. These barriers create a plausibly exogenous source of variation in the timing of municipalisation, as the barriers to municipalisation (and the delays resulting from those barriers) will vary from 
town to town. We exploit that variation to measure the extent to which municipalisation affected the typhoid fever fatality rate. Nevertheless, one might be concerned that cities are being opportunistic by proposing municipalisation after an extreme epidemic and that the observed decline in the typhoid fatality rate is the result of a natural mean-reverting process. The purpose of this section is to explore this possibility and fully control for any mean-reverting processes.

If the concern is that we are failing to account for autocorrelation in typhoid fever rates, then this can be addressed by including lagged typhoid rates on the right hand side. Of course, this leads to a natural question of how many lags are appropriate? In Table 9 we include a series of lagged typhoid rates and find that our results are largely unaffected. We present results for up the five lags in typhoid rates, but results are consistent even when including up to 10 lags. The results in Table 9 indicate that, even after explicitly controlling for the dynamics of typhoid fever, typhoid fever rates fell by approximately 13 percent following municipalisation.

Despite the fact that lagged typhoid rates do not affect our results, one could still be concerned that there is something inherently different about the dynamics of extreme epidemics. In Figure 5 we plot the average residuals from regressing the log of the typhoid rate on town and year fixed effects. This is the same process used to generate the residuals in Figure 4, however, instead of examining the residuals near the time of public acquisition (as we did in Figure 4), Figure 5 plots the residuals near the time of each town's four largest typhoid epidemics. What is immediately clear from Figure 5 is that large epidemics are not persistent across time. In each of the panels of Figure 5, the average residuals at the time of the epidemic are a clear outlier. Figure 5 also illustrates that typhoid rates don't fall below pre-epidemic levels after an epidemic occurs. In general, after an epidemic typhoid rates tend to oscillate near the pre-epidemic peak. Although Table 2 showed that epidemics did not predict municipalisation, this pattern suggests that even if municipalisation occurred shortly after an extreme epidemic, the decline in typhoid rates following municipalisation did not simply reflect a natural meanreverting process. 
Table 9: Municipalisation and $\ln ($ typhoid mortality rate) including lagged typhoid rates

\begin{tabular}{lccccc}
\hline \hline & $(1)$ & $(2)$ & $(3)$ & $(4)$ & $(5)$ \\
\hline & & & & & \\
Post acquisition indicator & $-0.1376^{* *}$ & $-0.1282^{* *}$ & $-0.1201^{*}$ & $-0.1099^{*}$ & $-0.1491^{* *}$ \\
& $(0.0636)$ & $(0.0620)$ & $(0.0641)$ & $(0.0665)$ & $(0.0679)$ \\
Pre-acquisition time trend & $0.0171^{* *}$ & $0.0174^{* *}$ & $0.0166^{*}$ & $0.0163^{*}$ & $0.0201^{* *}$ \\
& $(0.0082)$ & $(0.0081)$ & $(0.0087)$ & $(0.0092)$ & $(0.0096)$ \\
& & & & & \\
Post-acquisition time trend & -0.0009 & -0.0006 & -0.0005 & -0.0015 & -0.0012 \\
& $(0.0029)$ & $(0.0028)$ & $(0.0027)$ & $(0.0026)$ & $(0.0026)$ \\
Number of lags included & 1 & & & & \\
City fixed effects & $\mathrm{Y}$ & $\mathrm{Y}$ & 3 & 4 & 5 \\
Year fixed effects & $\mathrm{Y}$ & $\mathrm{Y}$ & $\mathrm{Y}$ & $\mathrm{Y}$ & $\mathrm{Y}$ \\
& & & & & $\mathrm{Y}$ \\
R-squared & 0.5516 & 0.5500 & 0.5500 & 0.5473 & 0.5439 \\
Observations & 10,086 & 9120 & 8378 & 7757 & 7217 \\
\hline \hline
\end{tabular}

Standard errors (clustered at the waterworks level) in parentheses.

$$
{ }^{*} \mathrm{p}<.1 * * \mathrm{p}<.05 * * * \mathrm{p}<.01
$$

Notes: Death rates are measured as deaths per 10,000 persons. The non-waterborne death rate includes deaths from smallpox, measles, scarlet fever, typhus, whooping cough, diphtheria, and violence. The pretrend turns on ten years prior to acquisition and runs until municipalisation. The post-acquisition time trend turns on once municipalisation occurs. Mortality data are from annual registrar general reports. Acquisition data are from The Water Works Directory and Statistics, 1907. 
Figure 5: Binned scatter plot of normalized $\ln ($ typhoid mortality rate) near time of epidemic
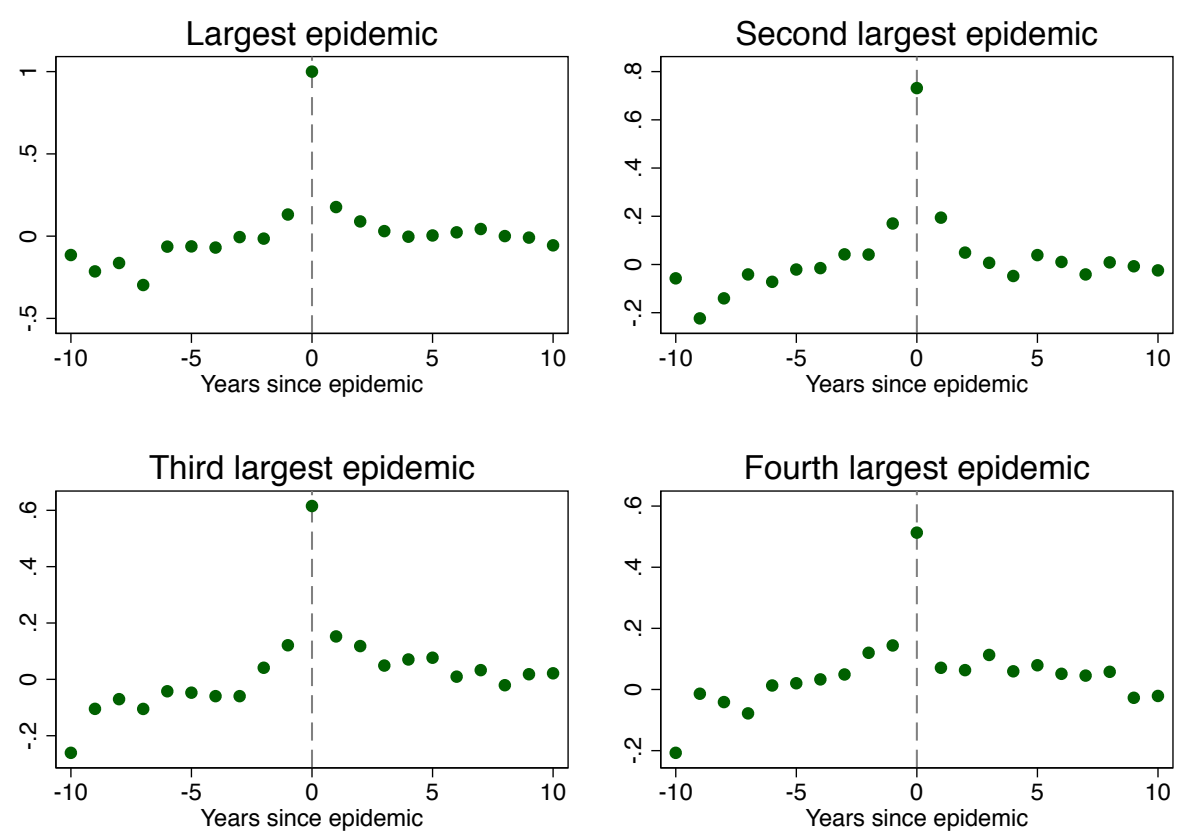

Notes: Death rates are measured as deaths per 10,000 persons. Observations correspond to the averaged normalized mortality rates, which are obtained by simply regressing the $\ln$ (death rate) on city and year fixed effects. Mortality data are from annual registrar general reports.

Even though Table 2 illustrates that cities were not exploiting large (and somewhat random) epidemics as an opportunity to municipalise their waterworks, it is perhaps useful to show that these epidemics are not driving our main results. In the first column of Table 10 we estimate our preferred specification (including pre and post acquisition time trends) excluding each town's largest epidemic years from our analysis. In the second column, we exclude the two largest epidemic years, column three excludes the three largest epidemic years, column four excludes the four largest epidemic years, and column five excludes the five largest epidemic years. The results are quite similar to the results presented in Table 3: municipalisation lowered typhoid fever fatality rates by approximately 15 percent. Of course, the results are less precisely measured as we exclude more and more data. Excluding five epidemic years worth of data for each registration district removes about 15 percent of the data from our analysis. 
Table 10: Sensitivity to large epidemics

\begin{tabular}{lccccc}
\hline \hline & $(1)$ & $(2)$ & $(3)$ & $(4)$ & $(5)$ \\
\hline Post acquisition indicator & & & & & \\
& $-0.1641^{* *}$ & $-0.1500^{* *}$ & $-0.1308^{*}$ & $-0.1177^{*}$ & $-0.1163^{*}$ \\
& $(0.0758)$ & $(0.0751)$ & $(0.0695)$ & $(0.0685)$ & $(0.0677)$ \\
Pre-acquisition time trend & & & & & \\
& $0.0215^{* *}$ & $0.0199^{* *}$ & $0.0186^{* *}$ & $0.0184^{* *}$ & $0.0199^{* *}$ \\
& $(0.0083)$ & $(0.0083)$ & $(0.0078)$ & $(0.0078)$ & $(0.0080)$ \\
Post-acquisition time trend & -0.0024 & -0.0031 & -0.0034 & -0.0037 & -0.0041 \\
& $(0.0036)$ & $(0.0036)$ & $(0.0036)$ & $(0.0036)$ & $(0.0037)$ \\
City fixed effects & & & & & \\
Year fixed effects & $\mathrm{Y}$ & $\mathrm{Y}$ & $\mathrm{Y}$ & $\mathrm{Y}$ & $\mathrm{Y}$ \\
Epidemics omitted & 1 & 2 & 3 & 4 & 5 \\
& & & & & \\
R-squared & 0.531 & 0.530 & 0.528 & 0.526 & 0.524 \\
Observations & 11,151 & 10,821 & 10,491 & 10,161 & 9,831 \\
\hline \hline
\end{tabular}

Standard errors (clustered at the waterworks level) in parentheses.

$$
* \mathrm{p}<.1 * * \mathrm{p}<.05 * * * \mathrm{p}<.01
$$

Notes: Death rates are measured as deaths per 10,000 persons. The non-waterborne death rate includes deaths from smallpox, measles, scarlet fever, typhus, whooping cough, diphtheria, and violence. The pretrend turns on ten years prior to acquisition and runs until municipalisation. The post-acquisition time trend turns on once municipalisation occurs. Mortality data are from annual registrar general reports. Acquisition data are from The Water Works Directory and Statistics, 1907.

\section{Timing and Sewers}

One possible concern with our analysis is that municipalisation might have gone hand-in-hand with other municipal interventions that are difficult to observe and control for, but might have had a beneficial effect on overall public health, including deaths from waterborne diseases. We propose two tests of this proposition. First, before the Public Health Act of 1875, the historical record suggests that municipal take overs were not generally aimed at improving waterborne disease rates, and few efforts to improve water quality appear to have followed these early municipalisations. Indeed, according the Cambridge World History of Disease (LeBaron and Taylor 1993, p. 1075) even though William Budd first documented the connection between water and typhoid fever in the late 1840 s, his ideas were actively and effectively opposed by those who (inaccurately) believed that the disease was generated spontaneously by poisonous atmospheres and miasmas. It was not until the early 1870s that public health officials in England fully embraced Budd's ideas. This embrace manifested in the Public Health of 1875, which, 
for the first time, held all municipalities in England responsible for providing pure water. ${ }^{23}$

Given all this, if it was truly improvements in water quality stemming from municipalisation that drove reductions in typhoid, we would expect public take overs before the Public Health Act of 1875 to have resulted in negligible reductions, if any at all, in typhoid rates. Instead, our results should be driven by post-1875 events. To assess this claim, we partition the sample by acquisition date (waterworks that were municipalised before and after 1875). The results are presented in Table 11. For cities that acquired their waterworks between 1869 and 1875, we find that typhoid fatality rates fell by a statistically-insignificant 3 percent. For waterworks acquired after 1875, we find results similar to our main results: public acquisition lowered the typhoid fever death rate by approximately 19 percent (significant at the 5-percent level). That said, because the standard error on the pre-1875 estimate is so large, we cannot reject the hypothesis that the two estimates are the same.

Table 11: Partitioning sample based on timing of acquisition

\begin{tabular}{lccc}
\hline \hline & $(1)$ & $(2)$ & $(3)$ \\
\hline & & & \\
Post acquisition indicator (pre-1875 acquisitions) & -0.0289 & -0.0723 & -0.0377 \\
& $(0.0831)$ & $(0.0881)$ & $(0.1117)$ \\
Post acquisition indicator (post-1875 acquisitions) & -0.0433 & $-0.210^{* *}$ & $-0.187^{* *}$ \\
& $(0.0687)$ & $(0.0825)$ & $(0.0812)$ \\
& & & \\
Pre-acquisition time trend & & $0.0241^{* * *}$ & $0.0231^{* *}$ \\
& & $(0.0092)$ & $(0.0092)$ \\
Post-acquisition time trend & & & -0.00204 \\
& & & $(0.0037)$ \\
City fixed effects & $\mathrm{Y}$ & $\mathrm{Y}$ & $\mathrm{Y}$ \\
Year fixed effects & $\mathrm{Y}$ & $\mathrm{Y}$ & $\mathrm{Y}$ \\
& & & \\
R-squared & 0.524 & 0.524 & 0.525 \\
Observations & 11,513 & 11,513 & 11,481 \\
\hline \hline
\end{tabular}

\footnotetext{
${ }^{23}$ It is generally accepted in the literature on local government in Britain that the post-1870-1875 years were substantially different to the earlier Victorian period (Bellamy 1988).
} 
Standard errors (clustered at the waterworks level) in parentheses.

$* \mathrm{p}<.1 * * \mathrm{p}<.05 * * * \mathrm{p}<.01$

Notes: Death rates are measured as deaths per 10,000 persons. The non-waterborne death rate includes deaths from smallpox, measles, scarlet fever, typhus, whooping cough, diphtheria, and violence. The pretrend turns on ten years prior to acquisition and runs until municipalisation. The post-acquisition time trend turns on once municipalisation occurs. Mortality data are from annual registrar general reports. Acquisition data are from The Water Works Directory and Statistics, 1907.

A second test addresses concerns that municipal governments simultaneously invested in sewers, sewage removal, or treatment at the same time they acquired waterworks. Recent research by Alsan and Goldin (2015) shows that investments in both water and sewerage were important for reducing infant mortality in Massachusetts during our time period. Thus, one might be concerned that the institutional changes that allowed cities to municipalise their waterworks also allowed cities to borrow for the purposes of building sewers. This would be particularly concerning if cities borrowed and started to construct sewers at the same time that they were trying to municipalise their waterworks. If this were true, then our observed decline in the typhoid fatality rate might result from the construction and extension of sewer networks, and not from increased investment in water. We are unaware of a source that would provide data on the extension of sewer networks throughout towns to allow us to formally test whether municipalisation and sewer construction were correlated. Instead, we use two approaches. First, looking at the dates when municipalizing towns completed intercepting sewers or other forms of sewage removal or treatment suggest that it is unlikely that sewer investments are driving our results. Secondly, we use data on loans given by the Local Government Board to local governments for sewers and sewage removal to infer whether significant sewerrelated investment was made prior to, or immediately following, waterworks acquisition.

We begin with three examples. Birmingham's investment in sewers and the removal of sewage pollution from the town took many years (Rosenthal, 2014: 57-89). The introduction of an interception system by Birmingham's Health Department in 1876 and the creation of the joint Birmingham, Tame and Rea District Drainage Board in 1877, might suggest that the council simultaneously invested in sewers as they acquired the waterworks in 1876. Rosenthal makes clear, however, that the sanitary changes brought about by these acts took a long time and built upon earlier initiatives. 
Nottingham committed to sewerage early and by 1866 had constructed three intercepting sewers to remove sewage from the town. The Nottingham and District Sewerage Act of 1872 addressed the resulting pollution of the river Leen. Even though construction of the Stoke Bardolph Sewage works was not fully complete until 1880, the year Nottingham acquired its waterworks, Nottingham had abandoned the river as a water source over fifty years previously so the impact of the sewage works on typhoid transmission was likely limited. More important might have been the Nottingham government's decision to abandon the Scotholme waterworks, one of five used by the acquired company, for domestic water supply given the groundwater's proximity to the river Lean. ${ }^{24}$

Reading, Berkshire, acted later to address water pollution. An 1866 inquiry into the means of preventing the pollution of rivers described the sanitary situation in Reading as "a system of cesspools still prevails; there are also numerous open privies discharging direct into the water." ${ }^{25}$ Possibly in response to this inquiry, Reading acquired its waterworks in 1869. This same year, the town was one of the first to apply for Parliamentary approval to use sewage sludge as fertilizer. Approval was granted in an act of 1870 but municipal investment in the Manor Farm sewage works did not begin until 1874, well after waterworks municipalisation.

Of course, it is not possible to provide a detailed history of sewer systems in all 117 districts that municipalise. We can, however, gather data on loans granted to local authorities for the purposes of investing in sewers, sewage removal, and sewage treatment. Specifically, we rely on annual reports of the Local Government Board. These reports include a detailed section on loans sanctioned by the Board to local governments that reports the purpose and amount of the loan. The purposes are incredibly detailed. Some examples include "purchase of site and erection of offices", "Burial ground and chapels", and "Channelling and flagging of streets." We transcribed and aggregated borrowing only for sewer purposes, which included entries such as "Extension of main sewerage", "Sewer ventilation", "Sewage tanks and outfall works", as well as "Sewers."

\footnotetext{
${ }^{24}$ For details of Nottingham's waterworks history, see Notts Water History (http://papplewickpumpingstation.co.uk/notts_w_history.htm) and Tarbotton (1866).

${ }^{25}$ Royal Com. 1866. See also Local Government Provisional Orders (No.4) 1873.
} 
The data we transcribed span from fiscal year 1872 to fiscal year 1908, and all reports were obtained from the House of Commons Parliamentary Papers database.

We construct a measure of borrowing that takes into account the fact that most cities do not borrow every year. Specifically, for each city, we calculate the total amount of money borrowed from 1872 to 1908. We then construct a cumulative borrowing variable that, for every year, computes the total amount of borrowing that has occurred thus far and divides that amount by the total borrowing over the entire sample period. Next, we use this measure to assess whether cities were building sewers near the time of municipalisation. First, we normalize borrowing by running a regression with year fixed effects to remove common trends. Then, we construct a binned scatter plot, similar to Figure 4, where we analyse normalized sewerage borrowing near the time of acquisition. The result of this exercise is presented in Figure 6. There we see that, in the years prior to municipalisation there is no systematic increase in borrowing for sewer-related purposes. In fact, the local polynomial line is close to zero, which suggests that the borrowing patterns of cities that municipalised their waterworks was nearly identical to the borrowing patterns of cities that did not municipalise their waterworks. This indicates that it is unlikely that our main results are simply being driven by systematic investment in sewers near the time of acquisition.

One feature of Figure 6 worth noting is the increase in borrowing that occurs roughly ten years after municipalisation. This suggests that, on average, governments that municipalised their works invested in sewers about ten years after municipalisation. The length of delay between this sewerage investment suggests that the decline in typhoid rates at the time of municipalisation (nearly ten years before governments begin borrowing to begin invest in sewerage infrastructure) is not being driven by contemporaneous sewerage investment. 
Figure 6: Normalized sewerage borrowing near the time of acquisition

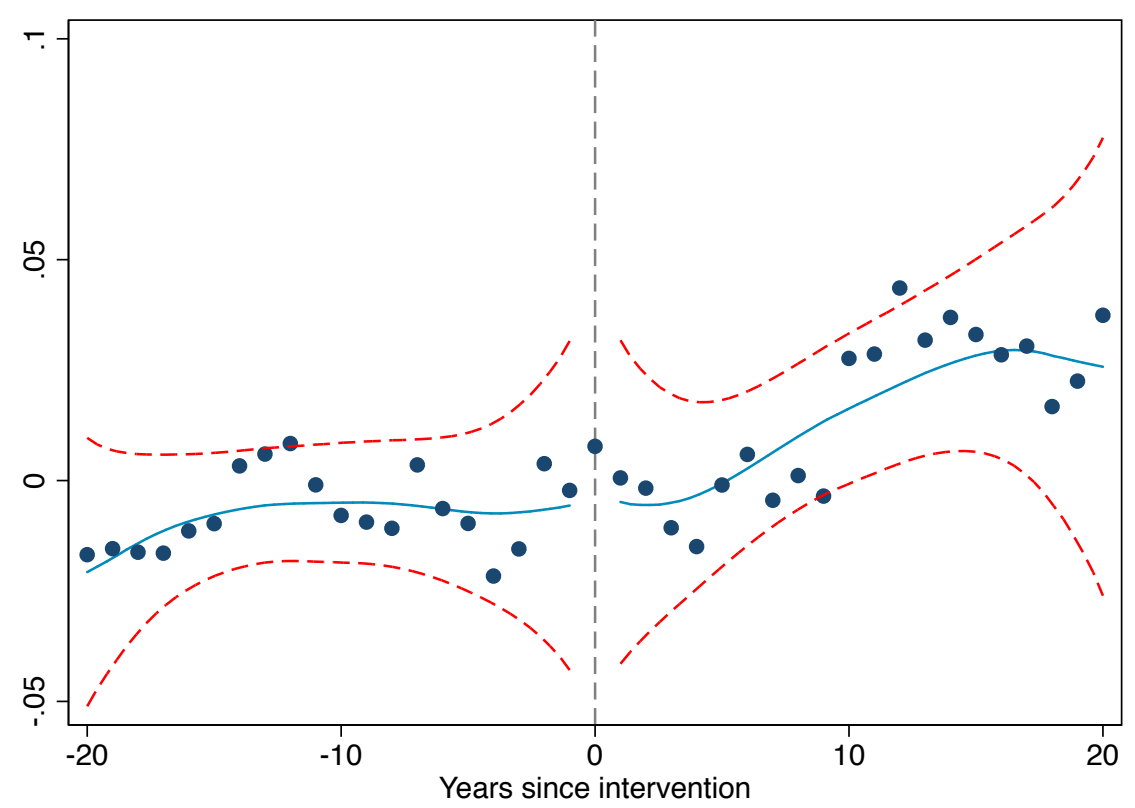

Standard errors (clustered at the waterworks level) in parentheses.

$* \mathrm{p}<.1 * * \mathrm{p}<.05 * * * \mathrm{p}<.01$

Notes: Loan data are from the annual reports of the Local Government Board. Acquisition data are from The Water Works Directory and Statistics, 1907.

To further illustrate that our results are not being driven by sewerage investment, we repeat our main analysis controlling for cumulative sewer borrowing. The results of this exercise (reported in Table 12) are statistically indistinguishable from the results in Table 3. Specifically, we see that when we control for cumulative sewer borrowing, the typhoid fatality rate fell by about 17.5 percent following municipalisation. Together, Figure 6 and Table 12 suggest that investment in sewers, the most likely confounding public health intervention, was not systematically occurring near the time of municipalisation. 
Table 12: The relationship between typhoid rates and public acquisition controlling for sewerage investment

\begin{tabular}{lccc}
\hline \hline & $(1)$ & $(2)$ & $(3)$ \\
\hline & & & \\
Post acquisition indicator & -0.0283 & $-0.193^{* *}$ & $-0.176^{* *}$ \\
& $(0.0691)$ & $(0.0796)$ & $(0.0809)$ \\
& & & \\
Pre-acquisition time trend & & $0.0250^{* *}$ & $0.0242^{* *}$ \\
& & $(0.0097)$ & $(0.0098)$ \\
& & & -0.00138 \\
Post-acquisition time trend & & & $(0.0036)$ \\
& & & \\
Cumulative sewer borrowing & -0.0481 & -0.0484 & -0.0414 \\
& $(0.0539)$ & $(0.0540)$ & $(0.0542)$ \\
City fixed effects & & & \\
Year fixed effects & $\mathrm{Y}$ & $\mathrm{Y}$ & $\mathrm{Y}$ \\
& $\mathrm{Y}$ & $\mathrm{Y}$ & $\mathrm{Y}$ \\
R-squared & & & \\
Observations & 0.539 & 0.540 & 0.540 \\
\hline \hline
\end{tabular}

Standard errors (clustered at the waterworks level) in parentheses.

$* \mathrm{p}<.1 * * \mathrm{p}<.05 * * * \mathrm{p}<.01$

Notes: Death rates are measured as deaths per 10,000 persons. The "All non-waterborne causes" death rate includes deaths from smallpox, measles, scarlet fever, typhus, whooping cough, diphtheria, and violence. The pre-trend turns on ten years prior to acquisition and runs until municipalisation. The post-acquisition time trend turns on once municipalisation occurs. Mortality data are from annual registrar general reports. Acquisition data are from The Water Works Directory and Statistics, 1907. Sewer borrowing data are from annual reports of the Local Government Board.

\section{Conclusion}

Taken together, our empirical results suggest the following narrative. In large and fast growing cities with older water works, population growth overwhelmed the ability of private suppliers to maintain and extend adequate water supplies. As a result, typhoid rates in those cities began to climb and eventually culminated in political pressures to municipalise the associated water system in the hope that such municipalisation would result in improved water quality. The results suggest that those hopes generally came to fruition, with typhoid rates falling by around 19 percent in the wake of municipalisation.

How does one reconcile the finding that public acquisition improved disease rates in Britain (and the U.S.) during the late-nineteenth and early-twentieth century, while 
privatization improved disease rates in late-twentieth-century Argentina? As suggested in the introduction, one possibility is that municipalisation and public ownership worked well in settings where there was high quality governance. In this regard, a group of American observers visiting Britain during the early 1900's claimed, "British cities . . . are recognized as among the best governed municipalities in the world" (Kellett 1978: 36). Consistent with this, municipalities were able to borrow at a lower rate than private firms. Thus, it is perhaps not too surprising that the municipalisation movement in $19^{\text {th }}$ century Britain was successful as existing infrastructure required additional investments and those investments were more feasible under municipal ownership.

\section{References}

Acemoglu, Daron, Suresh Naidu, Pascual Restrepo, and James Robinson. 2014. "Democracy does cause growth." National Bureau of Economic Research No. w20004.

Alsan, Marcella, and Claudia Goldin. 2015. "Watersheds in infant mortality: The role of effective water and sewerage infrastructure, 1880 to 1915." National Bureau of Economic Research, No. w21263.

Amsler, Christin, Robin Bartlett, and Craig Bolton. 1981. "Thoughts of some British economists on early limited liability and corporate legislation." History of Political Economy 13(4): 774-793.

Antman, Francisca. 2016. "For want of a cup: The rise of tea in England and the impact of water quality on economic development." Unpublished paper. Department of Economics. University of Colorado.

AquaFed. 2010. "Footprint of AquaFed members in Europe." Accessed May 19, 2015 at http://www.aquafed.org/pages/fr/admin/UserFiles/pdf/2011-0517 AquaFed European base.pdf

Beach, Brian, Joseph Ferrie, Martin Saavedra, and Werner Troesken. 2016. "Typhoid fever, water quality, and human capital formation." The Journal of Economic History 76 (1): 41-75.

Beach, Brian, and W. Walker Hanlon. 2016. "Coal smoke and mortality in an early industrial economy." Working paper.

Bellamy, Christine. 1988. Administering central-local relations 1871-1919. New York: St. Martin's Press. 
Chapman, Jonathan. 2016. "Local government sanitation investment and mortality from waterborne disease in England and Wales, 1871-1890." Working paper.

Charlesworth, Sidney. 1912. "Bridlington waterworks." Proceedings of the Institution of Municipal and County Engineers 38: 402-9.

Cutler, David, and Grant Miller. 2005. "The role of public health improvements in health advances: the twentieth-century United States." Demography 42 (1): 1-22.

Cutler, David, and Grant Miller. 2006. "Water, water everywhere. Municipal finance and water supply in American cities" in Corruption and reform: Lessons from America's economic history, eds. Edward L. Glaeser and Claudia Goldin, University of Chicago Press.

Donald, Robert (editor). 1902. The municipal yearbook of the United Kingdom for 1902. London: Edward Lloyd, Limited.

Engineering News, May, 1913, p. 1087

Falkus, Malcolm. 1977. 'The development of municipal trading in the nineteenth century', Business History, 19 (2): 134-61.

Ferrie, Joseph, and Werner Troesken. 2008. "Water and Chicago's mortality transition, 1850-1925.” Explorations in Economic History 45: 1-16.

Fuertes, James. 1897. Water and public health: The relative purity of waters from different sources. John Wiley \& Sons.

Galiani, Sebastian, Paul Gertler, and Ernesto Schargrodsky. 2005. "Water for life: The impact of the privatization of water services on child mortality." Journal of Political Economy 113 (1): 83-120.

Grafton Quenin, Katherina Daniell, Celine Nauges, Jean Daniel Rinaudo, and Noel Whai Wah Chan (editors). 2015. Understanding and managing urban water in transition. Springer-Verlag.

Hamlin, Christopher. 1988. "Muddling in Bumbledon: On the enormity of large sanitary improvements in four British towns, 1855-1885." Victorian Studies 32 (1): 55-83.

Hamlin, Christopher and Sally Sheard. 1998. "Revolutions in public health: 1848, and 1998?” BMJ: British Medical Journal 317: 7158 (587-591).

Hassan, J. A. 1985. "The growth and impact of the British water industry in the nineteenth century." Economic History Review 38 (4): 531-547.

Kellett, John. 1978. "Municipal socialism, enterprise and trading in the Victorian city." Urban History Yearbook 5: 36-45. 
Kesztenbaum, Lionel and Jean-Laurent Rosenthal. 2014. "Income versus sanitation: Mortality decline in Paris, 1880-1914." Paris School of Economics. Working Paper No. 2014-26.

Knoop, Douglas. 1912. Principles and methods of municipal trading. London: Macmillan and Co.

LeBaron, Charles and D. W. Taylor. 1993. The Cambridge World History of Human Disease.

Lizzeri, Alessandro and Nicola Persico. 2004. "Why did the elites extend the franchise?" Quarterly Journal of Economics 119 (2): 717-765.

MacDonagh, Oliver. 1977. Early Victorian government, 1830-1870. New York: Holmes $\&$ Meier.

McCulloch, C.S. 2004. "Political ecology of dams in Teesdale." In Long-term benefits and performance of dams (49-66). London: Thomas Telford.

Millward, Robert. 2013. The state and business in the major powers: An economic history 1815-1939. London: Routledge.

Millward, Robert, and Sally Sheard. 1995. "The urban fiscal problem, 1870-1914: Government expenditure and finance in England and Wales," The Economic History Review, 48 (3): 501-35.

Pérard, Edouard. 2009. "Water supply: Public or private? An approach based on cost of funds, transaction costs, efficiency and political costs." Policy and Society, 23 (3): 193-219.

Rosenthal, Leslie. 2014. The river pollution dilemma in Victorian England: Nuisance law versus economic efficiency. Farnham: Ashgate Publishing Limited.

Ryde, Walter C. 1894. The Local Government Act, 1894. London: Reeves and Turner.

Silverthorne, Arthur. 1881. The purchase of gas and water works. London: Crosby Lockwood and Co.

Silverthorne, Arthur. 1884. London and provincial water supplies with the latest statistics of metropolitan and provincial water works. London: Crosby Lockwood and Co.

Szreter, Simon. 1992. "Mortality and public health, 1815-1914." ReFRESH: Recent Findings of Research in Social and Economic History 14: 1-4..

Tarbotton, M.O. 1866. "Recent sanitary operations and town improvements." In Allen's illustrated hand-book and guide to all the places of interest in Nottingham and its environs (81-95). Nottingham: Richard Allen and Son. 
The Local Government Act, 1894, with full explanation notes an introductory chapter on local government; and an appendix containing the incorporated acts and the regulations of the Local Government Board by Walter C. Ryde, London: Reeves \& Turners.

The water works directory and statistics, 1907. London: Hazell, Watson and Viney LD. Twenty seventh issue.

Thompson, Carl Dean. 1917. Municipal ownership: A brief survey of the extent, rapid growth and the success of municipal ownership throughout the world, presenting arguments against private ownership, the failure of regulation and the advantages of municipal ownership. New York: B.W. Huebsch

Thorne, Sir Richard Thorne. 1879. "The recent outbreak of enteric fever at Caterham." In Annual Conference on National Water Supply, Sewage and Health.

Thornton, Judith, and Peter Pearson. 2013. "Bristol water works company: A study of nineteenth century resistance to local authority purchase attempts." Water History 5 (3): $307-330$.

Troesken, Werner. 1999. "Typhoid rates and the public acquisition of private waterworks, 1880-1920.” The Journal of Economic History 59 (4): 927-48.

Troesken, Werner. 2001. "Race, disease, and the provision of water in American cities, 1889-1921." The Journal of Economic History 61 (3): 750-76.

Troesken, Werner. 2004. Water, race, and disease. MIT Press.

Troesken, Werner, and Rick Geddes. 2003. "Municipalizing American waterworks, 1897-1915." Journal of Law, Economics, and Organization 19 (2): 373-400.

Tynan, Nicola. 2002. "London's private water supply, 1582-1902.” In Reinventing water and wastewater systems, Paul Seidenstat, David Haarmeyer, and Simon Hakim (eds.), John Wiley \& Sons.

Whipple, George. 1908. Typhoid fever: Its causation, transmission and prevention. J. Wiley \& sons.

Wohl, Anthony S. 1983. Endangered lives: Public health in Victorian Britain. Harvard University Press.

Wright, George. 1902. Municipal Socialism: A series of articles reprinted from the Times (London: Printed and Published by George Edward Wright). 